\title{
Boyle versus the Galenists: a Suppressed Critique of Seventeenth-Century Medical Practice and its Significance
}

\author{
MICHAEL HUNTER*
}

Medicine was integral to Robert Boyle's vision for natural philosophy. He saw medicine as "being a part, or an application of natural philosophy", and the amelioration of human life was one of the criteria directing his scientific programme: indeed, in a hitherto little-known memorandum dating from his later years, he even claimed that his famous pneumatical researches were inspired by the hope that they "might direct him in many usefull things for the Regiment of our health". ${ }^{1}$ Either directly or indirectly, a high proportion of Boyle's published output was concerned with medical subjects, and it is therefore appropriate that of late his medical concerns have begun to receive the attention that they deserve, after a long period in which the only available accounts of them were generalized and often rather patronizing.

First, in 1980 Robert G Frank published his splendid account of Boyle in the context of the "Oxford physiologists" of the 1650s and 1660s. ${ }^{2}$ More recently, in 1993, a book-length study of Boyle's medical ideas has appeared in the form of Barbara Kaplan's 'Divulging of Useful Truths in Physick': the medical agenda of Robert Boyle. ${ }^{3}$ This is based on a dutiful perusal of a wide range of relevant sources and it gives a useful account of various aspects of Boyle's medical thought. Kaplan is perhaps at her best in expounding the implications for his approach to illness and medication of Boyle's corpuscularian view of

*Professor Michael Hunter, Department of History, Birkbeck College, University of London, Malet Street, London, WC1E 7HX.

I am grateful to the following for their comments on a draft of this paper: William Birken, Harold J Cook, Mordechai Feingold, Rob Iliffe, Malcolm Oster, Jan Wojcik and two anonymous referees. I also benefited from the discussion that followed my oral presentation of a draft of it at the following universities in 1993: Auburn University; University of Alabama at Birmingham; Emory University; Harvard University; Johns Hopkins University; University of North Carolina; and Virginia Polytechnic Institute and State University. The research on which the paper is based was supported by a generous grant from the Wellcome Trust. My work on the Boyle Papers was greatly facilitated by the help of the library staff at the Royal Society.

\footnotetext{
${ }^{1}$ Thomas Birch (ed.), The works of the Hon. Robert Boyle, 2nd ed., 6 vols, London, printed for J and F Rivington, etc., 1772, vol. 5, p. 583; Michael Hunter (ed.), Robert Boyle by himself and his friends, London, William Pickering, 1994, p. 29.

${ }^{2}$ R G Frank, Harvey and the Oxford physiologists: a study of scientific ideas and social interaction, Berkeley and Los Angeles, University of California Press, 1980. For earlier studies, see G W Jones, 'Robert Boyle as a medical man', Bull. Hist. Med., 1964, 38: 139-52; L S King, 'Robert Boyle as amateur physician', in C W Bodemer and L S King, Medical investigation in seventeenth-century England, Los Angeles, William Andrews Clark Memorial Library, 1968; idem, The road to medical enlightenment 1650-95, London, Macdonald, 1970, pp. 62-86.

${ }^{3}$ B B Kaplan, 'Divulging of Useful Truths in Physick': the medical agenda of Robert Boyle, Baltimore, Johns Hopkins University Press, 1993.
} 


\section{Boyle versus the Galenists}

matter, and in indicating his preoccupation with environmental influences on the human body, in which, as she points out, he significantly foreshadowed eighteenth-century developments. In all, Kaplan gives a good sense of the integrity of Boyle's medical concerns to his general natural philosophical programme.

On the other hand, in a relatively short book Kaplan was inevitably unable to get to the bottom of many aspects of this important subject. She offers disappointingly little detail on the actual-and often slightly surprising-content of Boyle's medical writings; his interest in a wide range of sometimes strange cures; and his receptiveness to the ideas of thinkers like J B van Helmont. Indeed, she displays a rather disquieting tendency to "modernize" Boyle which is at odds with recent developments in Boyle scholarship. ${ }^{4}$ In addition, although Kaplan makes some attempt to deploy evidence from Boyle's voluminous surviving manuscripts, she does so only in a rather partial way, failing to draw out the full significance of the material therein contained.

In this paper, I wish to make full use of relevant documents in the Boyle archive to give a definitive account of an aspect of Boyle's medical ideas which is more complex, and more revealing, than Kaplan implies. This is Boyle's concern with the actual practice of medicine, as against what might be described as medical science-the medical spin-offs of his broader scientific programme. The practice or "art" of medicine was the subject of intense debate at the time, and strongly entrenched views were held as to how it should be carried out and how it might be improved. Many continued to champion the traditional methodus medendi, which combined diagnosis according to principles derived from the writings of Galen with a therapy dominated by blood-letting and other forms of evacuation. But this had come under attack from a tradition of chemical medicine that had originated with Paracelsus in the early sixteenth century. Matters were further complicated by the extent to which this conflict between "learned" and "empirical" physic overlapped with bitter professional and institutional rivalry between physicians and apothecaries. ${ }^{5}$ In all, it was a highly controversial field, as Boyle was to discover to his cost.

In so far as Kaplan deals with such matters, she sees Boyle as adopting an eirenic position in such disputes. "Boyle's nonconfrontational demeanor (in person and in print) was legendary", she writes, and she sees him as "deliberately expressing his ideas on medicine with extreme caution and subtlety. He repeatedly reminded his readers that he

\footnotetext{
${ }^{4}$ See esp. Antonio Clericuzio, 'A redefinition of Boyle's chemistry and corpuscular philosophy', Ann. Sci., 1990, 47: 561-89, and the studies in Michael Hunter (ed.), Robert Boyle reconsidered, Cambridge University Press, 1994.

${ }^{5}$ On these debates, see H J Cook, The decline of the old medical regime in Stuart London, Ithaca, Cornell University Press, 1986, esp. ch. 4; idem, 'The new philosophy and medicine in seventeenthcentury England', in D C Lindberg and R S Westman (eds), Reappraisals of the scientific revolution, Cambridge University Press, 1990; idem, 'Good advice and little medicine: the professional authority of early modern English physicians', J. Br. Stud., 1994, 33: 1-31; Charles Webster, The great instauration: science, medicine and reform 1626-60, London, Duckworth, 1975, ch. 4; idem, 'Alchemical
}

and Paracelsian medicine', in Charles Webster (ed.), Health, medicine and mortality in the sixteenth century, Cambridge University Press, 1979; P M Rattansi, 'The Helmontian-Galenist controversy in Restoration England', Ambix, 1964, 12: 1-23; and R F Jones, Ancients and moderns: a study of the rise of the scientific movement in seventeenth-century England, 2nd ed., St Louis, Washington University Studies, 1961, pp. 206f. On the specific issue of the methodus medendi, see Jeffrey Boss, 'The Methodus Medendi as an index of change in the philosophy of medical science in the sixteenth and seventeenth centuries', Hist. Philos. Life Sci., 1979, 1: 13-42; Donald G Bates, 'Sydenham and the medical meaning of "method"', Bull. Hist. Med., 1977, 51: 324-38. 


\section{Michael Hunter}

was, after all, a layman, yet one who was anxious to make suggestions in the hope that professional physicians, who were more 'knowledgeable' about medical matters, might find them useful and be willing to expand upon them on their own". ${ }^{6}$ In this, she echoes a view of Boyle that has lately become commonplace, particularly through the influential writings of Steven Shapin, which present an image of Boyle as an intellectual strategist who loftily transcended disputes over professional demarcation and the like. ${ }^{7}$

In fact, however, this paper will argue that Boyle's relations with the medical profession were more ambivalent, and more troubling for him, than such views imply. I will argue that Kaplan's view that "Boyle sought accommodation, not revolution"8 ignores the extent to which this was a position forced on him, rather than adopted by choice. Indeed, the thrust of this paper is that Boyle was able to achieve less in the medical sphere than he would have liked, a state of affairs with significant implications for our understanding both of Boyle and his milieu.

The key evidence for this is a treatise on which Boyle worked over many years, in which he expressed strong and iconoclastic views about orthodox medical practice, with particular reference to the methodus medendi and how it could be improved. Ultimately, however, he suppressed it, and today only fragments of it survive among the Boyle Papers. Two scholars have come across one of these and quoted from it piecemeal-one of them Barbara Kaplan - but they have failed to understand its true significance due to ignorance of its context. ${ }^{9}$ In this paper, I intend to set out the evidence concerning this suppressed text in full, publishing the extant fragments of it, and utilizing other relevant material from among both Boyle's published and unpublished works to throw light on his motives and preoccupations, first in writing the piece and then in suppressing it. In addition, as I will show, elucidation of this key episode throws new and important light on the origins of the medical works that Boyle did publish in his later years.

That Boyle wrote a work on the practice of medicine that he suppressed is confirmed by tantalising hints that he himself incorporated in his later publications on related topics. In the Discourse about the advantages of the use of simple medicines appended to his $O f$ the reconcileableness of specific medicines to the corpuscular philosophy of 1685, he wrote: "I had once thoughts of drawing up a discourse of the difficulties of the medicinal art, and had divers materials by me for such a work, which afterwards I laid aside, for fear it should be misemployed to the prejudice of worthy physicians". ${ }^{10}$ A similar passage occurs in his 'Advertisement touching those Passages, that in this Book relate to the Art of Medicine' in his Experimenta \& observationes physica (1691), where he explains in similar terms how he began but abandoned such a work. Here, he presents it as a sequel that he was encouraged to write to the first section of the second book of his Some considerations touching the usefulness of experimental natural philosophy (1663), which was Boyle's most significant medical publication. A manuscript draft of the passage in

\footnotetext{
${ }^{6}$ Kaplan, op. cit., note 3 above, pp. 144, 172. Cf. chs. 6-7 passim.

${ }^{7}$ Steven Shapin, A social history of truth: civility and science in seventeenth century England, University of Chicago Press, 1994, esp. ch. 4. See further below, pp. 340-2.

${ }^{8}$ Kaplan, op. cit., note 3 above, p. 155.
}

\footnotetext{
${ }^{9}$ See Kaplan, op. cit, note 3 above, pp. 138-9 and 199 nn. 3-6; Rose-Mary Sargent, The diffident naturalist: Robert Boyle and the philosophy of experiment, University of Chicago Press, 1995, p. $255 \mathrm{nn} .87,97$.

${ }^{10}$ Boyle, op. cit., note 1 above, vol. 5, p. 116.
} 


\section{Boyle versus the Galenists}

question specifies how he was encouraged by the success of Usefulness "to think of inlarging the next Edition of my Book, by offering some Proposals towards the improvement of most of the several parts of Physick". However, he went on to explain how the attitude of certain doctors meant that he "laid aside the papers I had written in reference to the physician's art", and instead "suffered myself without much violence to be diverted to other studies more suitable to my inclinations, as well as to my condition".11

As will be noted, these remarks imply that the treatise in question would have been substantially concerned with medical practice. It is important to note that it would thus have been rather different from the writings that Boyle actually published, which dealt with medical science more generally. Apart from the medical sections of his Usefulness of natural philosophy and Experimenta \& observationes physica, and his Of the reconcileablness of specific medicines to the corpuscular philosophy, that have already been referred to, these were his Memoirs for the natural history of humane blood (1684) and his Medicina hydrostatica: or hydrostaticks applied to the materia medica (1690) (as we will see, there is also a significant medical component in Boyle's more theoretical Free enquiry into the vulgarly receiv'd notion of nature (1686)). The significance of the contrast between the subject matter of these mainly later books and the suppressed work will be explored in the course of this paper. The result, it is hoped, will be to throw fresh light both on Boyle's intellectual personality, and on the relations between science and medicine in his period.

\section{Boyle's Usefulness of Natural Philosophy and its Aftermath}

Our story must begin with the book to which, as Boyle stated, the suppressed work was an intended sequel, the medical section of his well-known treatise on the utility of natural philosophy: the first section of the second part of this, 'Of its usefulness to physick', published in 1663 , had been written during the late $1650 \mathrm{~s}^{12}$ This vast compendium more or less explicitly divulges the themes of all Boyle's subsequent writings on medical topics. Its organizing theme (as its title suggests) was the utility of scientific knowledge to medicine, and this was illustrated in a sequence of essays dealing with the traditional five parts of the medical "institutes"-"physiological", "pathological", "semeiotical", "hygienial" and "therapeutical"-in other words, the way in which medicine was subdivided in textbooks of the day.

Around this framework, Boyle hung a vast quantity of material, often of a quite miscellaneous kind. Thus the work is full of profusely-recounted examples of the use to medicine of scientific findings and techniques: the dissection of non-human carcases, chemical distillations and amalgams, and the theory of corpuscularianism which could explain both the expected and the unexpected in nature. ${ }^{13}$ An equally major feature of the

\footnotetext{
11 Ibid., vol. 5, pp. 583-4, based on draft versions in Royal Society Boyle Papers (hereafter BP) 18, fols. 99-100 (copied in BP 36, fol. 12) and BP 35, fol. 209 (for a full collation see the forthcoming 'Pickering Masters' edition of The works of Robert Boyle). The first part of the quotation is from the version in BP 36, fol. 12.
}

\footnotetext{
12 See the forthcoming 'Pickering Masters' Boyle, which will include a complete tabulation of the extensive draft material for this work surviving among the Boyle Papers.

${ }^{13}$ Boyle, op. cit, note 1 above, vol. 2, pp. 64-246, passim.
} 


\section{Michael Hunter}

work was its divulging of a vast number of medical recipes which Boyle had come across and had tried out, reflecting both the anxiety about his health which he felt from the early 1650 s onwards, and the enthusiasm for self-medication that he shared with many members of the landed classes in early modern England-even if, characteristically, he took such practices much further than most. ${ }^{14}$ Every section of The usefulness of natural philosophy contains a mass of such information collected from a wide range of sources, learned and unlearned, which Boyle justified as valuable in its own right and which apparently went down well with the book's readers, as Boyle's subsequent references to it testify. ${ }^{15}$ Moreover this side of the work reached a climax in its book-length appendix, which Boyle mainly devoted to the exposition of three novel and effective remedies, spirit of hartshorn, balsam of sulphur, and a copper compound known as Ens veneris. ${ }^{16}$

In addition, Boyle could hardly avoid taking up a position in the virulent debate then raging between Galenic and chemical physicians. Since the empiricism of natural philosophers like himself was frequently seen as allying them to empirics in medicine, Boyle was under some obligation to define his own position on the issue. In this work, he presents himself as a "naturalist"- "well versed both in chymical experiments, and in anatomy, and the history of diseases, without being too much addicted either to the chymists notions, or to the received opinions of physicians"-consciously attempting to pursue an intermediate position. For instance, in a lengthy passage "concerning the curableness of all diseases", he sought to show that the two sides were to some extent at cross purposes, and that a recognition of this might "conduce much to reconcile the two opinions, if not the parties that maintain them". Both here and elsewhere in the work, passages critical of Galenic practice were balanced by others equally critical of "the chymists", since Boyle wished to make it clear that he was as hostile to uninformed empiricism as he was to narrow Galenism. ${ }^{17}$

The result was that, on the issue of just where he stood on what was desirable in medical practice, the book is somewhat equivocal (quite apart from the extent to which its rather chaotic format neutralized any potential polemical thrust). Essentially Boyle argued for a medical pluralism, the implication of his provision of the vast store of information that the book contained being that traditional medical practice was imperfect and could usefully be supplemented, both from knowledge and techniques deriving from natural philosophy, and from the use of medications such as those that he retailed. But he went out of his way to stress that his aim was to supplement existing knowledge and practice, not to replace it. Throughout, passages stating that medicine was imperfect and that there was as yet much to be learnt were interspersed by others reassuring conservatives that he was not threatening the values they stood for, and that information derived from natural

\footnotetext{
14 On amateur medication see Paul Slack, 'Mirrors of health and treasures of poor men: the uses of the vernacular medical literature of Tudor England', in Webster (ed.), op. cit., note 5 above; Lucinda $\mathbf{M}$ Beier, Sufferers \& healers: the experience of illness in seventeenth-century England, London, Routledge and Kegan Paul, 1987; Cook, op. cit., note 5 above, ch. 1. 583.
}

\footnotetext{
16 Ibid., vol. 2, pp. $202 f$.

${ }^{17}$ Ibid., vol. 2, pp. 84, 91 and passim. For Boyle's views on such uninformed empiricism, see further Michael Hunter, 'The reluctant philanthropist: Robert Boyle and the "Communication of Secrets and Receits in Physick"', in O P Grell and Andrew Cunningham (eds), Religio medici: medicine and religion in seventeenth-century England, Aldershot, Scolar, 1996, pp. 250, 259.
} 


\section{Boyle versus the Galenists}

philosophy could be seen as tangential to the core doctrines on which their practice was based. Even when, at one point, he screwed himself up to write: "it would be worth an impartial disquisition, whether, since the methodus medendi ought to be grounded on, and accommodated to, the doctrine of diseases, the new anatomical discoveries formerly mentioned, and others not yet published, do not, by innovating divers things in pathology, require some alterations and amendments in the methodus medendi?", his response was that "in this particular, I dare yet affirm nothing". ${ }^{18}$ In addition, in this work as later, Boyle included passages explaining why he, who was not a doctor, was intervening in the medical sphere: "I am far from pretending to be a doctor in that faculty", he wrote near the start, and he reverted to this theme towards the end, explaining that he was precluded from the practice of medicine by his youth and status. Moreover, this need to account for the fact that a non-doctor was writing on medical subjects also recurs in the prefatory comments of Boyle's Oxford colleague, Robert Sharrock. ${ }^{19}$

Boyle's ambivalence helps to explain how the book was received. Its publication coincided with the outbreak of an intensive bout of infighting between the Galenists and the chemical physicians, and both sides were able to cite passages from the work which they claimed revealed Boyle as supporting them. Despite Boyle's attempts at balance, the very fact that he gave an equal hearing to non-traditional and to traditional methods seemed to align him with the reformers, while a similar conclusion might be drawn from his links with Samuel Hartlib, whose circle included many with iconoclastic views on such matters. ${ }^{20}$ It is therefore hardly surprising that the advocates of chemical therapy saw Boyle as an ally, assiduously appealing to his authority in the dispute. In particular, the former Republican pamphleteer, Marchamont Nedham, in his Medela medicina (1665), the chief anti-Galenic work, repeatedly quoted passages from The usefulness of natural philosophy which, he claimed, revealed "that noble and industrious person Mr Boyle" as a supporter of his and his allies' position, though he acknowledged Boyle's caution on such matters. Nedham's use of Boyle's book reached a peak as his argument came to its climax. He explained:

This Testimonie of so worthy a person I have set down at large, that I might deliver my own Sence, in the language of one well-known to the world for Sufficiencie, by reason of the great expence of time that he hath made in Medicinal Inquiries, continual Converse with Physicians of all sorts, and observation of Practise both Rational and Emperical.

The passages Nedham cited included ones showing that Boyle "thought it not beneath his dignity to record divers receipts that he had from Mountebanks, yea, and from Gypsies", others in which he was critical of Galen and Hippocrates, and others "where he implieth, there is no such need of Learning (commonly so reputed) to make a good Physician" (though he conceded that Boyle would not "be reckoned an enemy to Learning and Learned men"). He concluded: "Now my end in reciting all these Passages, is, to give some countenance to my own Conceptions, and the Judgment of others, who long for a renouncing of the antient Methods and Medicins". 21

\footnotetext{
${ }^{18}$ Boyle, op. cit., note 1 above, vol. 2, p. 154. Cf. ibid., pp. 89f., 114, 185, 389f.

${ }^{19}$ Ibid., p. 66. Cf. ibid., pp. 2 (invoking his "native honour": see below, p. 341), 199, 201, 240.

${ }^{20}$ See Hunter, op. cit., note 17 above, p. 257 . See
}

also Webster, op. cit., note 5 above, ch. 4 , and the other works cited in note 5 .

${ }^{21}$ Nedham, Medela medicina, London, for Richard Lownds, 1665, pp. 206, 210-11, 218, 226, 487, and passim. 


\section{Michael Hunter}

Similarly, at least some of the writers who defended the virtues of traditional Galenic therapy saw Usefulness as a dangerous reformist treatise. Thus Nathaniel Hodges wrote in his Vindicia medicinae \& medicorum (1665): "I very much wonder that the honorable $\mathrm{Mr}$ Boile should so much favour the practise of Empericks", and, quoting a passage in The usefulness in which Boyle argued how much doctors could learn from such sources, he went on:

Which expressions seem very much to plead for free practice ... verily the accomplishments of Physicians are very mean in the opinion of this honorable person, that may not be inconsiderably encreased by such inferior and improbable additions: but the case of Physicians as yet is not so desperate, as that to prevent sinking they should grasp at small rotten sticks and straws to be their treacherous support: did I not believe that these lines fell as a casual blot from this honorable persons Pen, I should more strictly examine them. ${ }^{22}$

The physician and controversialist, Henry Stubbe, comparably told Boyle in 1669 that "if any great difference appear betwixt you and me, it will be about the second part of your Usefulness in Experiments for Physic; in which book I think we physicians do suffer much; and that book hath been the occasion of all the insolencies we have received from Dowde to Glanvill and Thompson; wherein yet your candour would unconcern you, but that others make too much use of it to our prejudice". 23

On the other hand, the fact that Boyle had studiously expressed respect for Galenic principles even while canvassing alternative ones meant that, though some defenders of the status quo saw Boyle as an accomplice of the reformers and attacked him accordingly, the more standard response was to invoke him as an ally, taking Nedham and others to task for quoting Boyle out of context, and illustrating how Boyle was in fact deeply respectful of learning, medical as much as other. As Robert Sprackling put it in the first such assault on Nedham's "proud and provoking Treatise": "because the authority of the Honourable Mr Boyle, a great advancer and ornament of Learning, is so frequently (though impertinently) introduced by the Pleader, to exclude out of the true practice of Physique the ancient method and Medicines, I shall give him, both of them and all sorts of new ones, his plain sence in his own modest and judicious expression of it". Sprackling concluded: "'Tis evident that this learned person approveth the ordinary method and Remedies, as rational and unsuspected, although in cases extraordinary he alloweth others, as Physicians now adays do". ${ }^{24}$ John Twysden, in his Medicina veterum vindicata (1666) similarly sought "to silence all Calumnies that by Consequences [sic] of their own drawing out of his [Boyle's] words, contrary to his meaning, may be pinn'd upon him", citing omissions from Nedham's quotations from Boyle to "let the world judge what

\footnotetext{
22 Hodges, Vindicia medicina \& medicorum, London, 1665, reprinted 1666, J[ohn] F[ield] for Henry Broom, pp. 24-5.

${ }^{23}$ Boyle, op. cit., note 1 above, vol. 1, p. xciv. For elucidation of the background to Stubbe's attack, including the authors to whom he refers, see $\mathbf{H ~ J}$ Cook, 'Physicians and the new philosophy: Henry Stubbe and the virtuosi-physicians', in Roger French
}

and Andrew Wear (eds), The medical revolution of the seventeenth century, Cambridge University Press, 1989. Cf. the further, anonymous medical attack on Boyle of $c .1670$ noted in Cook, op. cit., note 5 above, p. 175.

${ }^{24}$ Sprackling, Medela ignorantia, London, W G for Robert Crofts, 1665, sig. A2, pp. 33-4. Cf. pp. 65, 118-19 and passim. 


\section{Boyle versus the Galenists}

ingenuity there is in this Citation, as he has mangled it". Professing an intimate acquaintance with Boyle and his laboratory (which is in fact hard to substantiate), Twysden stressed that, to his knowledge, Boyle was "a Scholar and Valuer of Learning", lacking in "that arrogance and pride of his Own Knowledge above Others" which he saw as characteristic of Nedham and his ilk. ${ }^{25}$

In fact, such views formed the basis of what became the leading public response of the medical establishment, building on precedents going back to the Interregnum, when the College of Physicians had been likened to Francis Bacon's "Solomon's House". ${ }^{26}$ It was claimed that it was learned physicians who were in the forefront of responsible innovation in medicine; that men of this kind had made breakthroughs in understanding the working of the human body, stemming from Harvey's discovery of the circulation of the blood; that they routinely used chemical remedies when these were appropriate; but that all of this formed part of a commitment to the traditional rules of regimen, without which any attempt at medical practice was defective. This line was taken by such authors as Robert Sprackling, George Castle and Daniel Coxe, invariably quoting Boyle profusely, including such works as The sceptical chymist (1661) and Certain physiological essays (1661) as well as The usefulness of natural philosophy. This provided the principal intellectual rationale for the reassertion of the role of traditional physic, and of the College of Physicians as its institutional guardian, from the late 1660 s onwards. ${ }^{27}$

Moreover, during the years following the publication of The usefulness of natural philosophy, Boyle was associated with the medical research in which these authors took such pride. He was the recipient of the dedications of various treatises exemplifying this tradition, including Richard Lower's vindication of Thomas Willis' study of fever, one of the quintessential productions of this school, and Walter Needham's disquisition on the formation of the foetus. ${ }^{28}$ In 1666, Boyle was also the dedicatee of Thomas Sydenham's Methodus curandi febris, in which Sydenham stated that he had undertaken the subject on Boyle's "persuasion and recommendation" and in which he claimed that Boyle had accompanied him on his visits to the sick; the implication was that Boyle was aware of

\footnotetext{
25 Twysden, Medicina veterum vindicata, London, for John Crook, 1666, pp. 114f., 213-14. I find it curious that Twysden receives no mention in the accounts of the scientific circles in which Boyle moved in the 1650 s in Webster, op. cit., note 5 above, or Frank, op. cit, note 2 above. But for a sympathetic account of Twysden see King, op. cit., note 2 above, pp. $154-60$.

${ }^{26}$ Charles Webster, 'The College of Physicians: "Solomon's House" in Commonwealth England', Bull. Hist. Med., 1967, 41: 393-412.

${ }^{27}$ Spracking, op. cit., note 24 above, esp. pp. 50-66, 93f.; George Castle, The chymical Galenist, London, Sarah Griffin for Henry and Timothy Twyford, 1667, pp. 11, 16-17, 41, 101 and passim; Daniel Coxe, A discourse wherein the interest of the patient in reference to physick and physicians is
}

soberly debated, London, for C R, 1669, pp. 89-90 and passim; Cook, op. cit, note 5 above, pp. $164 \mathrm{f}$. and ch. 5; T M Brown, 'The College of Physicians and the acceptance of iatromechanism in England, 1665-95', Bull. Hist. Med., 1970, 44: 12-30; R G Frank, 'The physician as virtuoso in seventeenthcentury England', in Barbara Shapiro and R G Frank, English scientific virtuosi in the sixteenth and seventeenth centuries, Los Angeles, William Andrews Clark Memorial Library, 1979.

28 J F Fulton, A bibliography of the Hon. Robert Boyle, 2nd ed., Oxford, Clarendon Press, 1961, pp. 160-2; Frank, op. cit., note 2 above, pp. 188f. For Boyle's references to Willis in his later medical writings, see Boyle, op. cit., note 1 above, vol. 4, pp. 619,637 , vol. 5 , pp. 74, 80, 97. 


\section{Michael Hunter}

and approved of the careful descriptive therapy that Sydenham exemplified in that and other works. ${ }^{29}$ At this time, Boyle was also part of a team of researchers who were pioneering improved understanding of the human body and its relationship with the environment. In conjunction with Richard Lower, John Locke and others he was carrying out an analysis of the characteristics and component parts of human blood, and it is clear that at least some of the material that was to be published in his Memoirs for the natural history of humane blood (1684) was collected at this time, though no relevant manuscripts of this date survive among Boyle's papers. In addition, Boyle was involved in experiments aimed to extend understanding of respiration and its role that he had begun at Oxford in the late 1650s, which were to result in the pioneering attempts at blood transfusion which took place at Oxford and London in these years. ${ }^{30}$

This being the case, it might have seemed likely that, in so far as Boyle considered making additions to the medical sections of The usefulness of experimental philosophy, these would have been of similarly scientifically-oriented material. Indeed, this is the implication of a remark that he made in a letter to Henry Oldenburg of 17 October 1667, after commenting on experiments with blood of the kind typical of the "Oxford" school: "And I shall on this occasion add in reference to Anatomicall matters in general, that after I saw, how favourably the Usefulness of Experimental Philosophy was receiv'd, I was invited to inlarge it in another Edition; and for that, I provided divers Anatomical as well, as other Experiments, and design'd many more, so that I have by me if I have not lost them divers things, that would not perhaps be unwelcome to Anatomists". ${ }^{31}$

If he did aspire to a publication of this kind, however, no manuscripts relating to it survive that can be dated to this period. ${ }^{32}$ What do survive in the handwriting of amanuenses which can definitely be dated to the mid-1660s are fragments of a book of a very different kind-an overt attack on orthodox medical practice of the kind that Boyle had fought shy of in The usefulness of natural philosophy. Despite the links with medical men documented in the previous paragraphs, and despite the extent to which Usefulness might have brought him unwelcome notoriety in the medical debates of the day, Boyle now took up certain key themes of Usefulness and gave them a newly polemical edge. Let us therefore turn to this work, exploring what can be learned about it and its significance.

${ }^{29}$ Fulton, op. cit., note 28 above, p. 161. See also the letter from Sydenham to Boyle of 2 April 1668 in Kenneth Dewhurst, Dr Thomas Sydenham: his life and original writings, London, Wellcome Historical Medical Library, 1966, pp. 162-4. On Boyle's links with Sydenham see also G G Meynell, Materials for a biography of Dr Thomas Sydenham, Folkestone, Winterdown Books, 1988, pp. 29-30.

${ }^{30}$ See esp. Frank, op. cit., note 2 above, chs. 5-7. See also Kenneth Dewhurst, 'Locke's contribution to Boyle's researches on the air and on human blood', Notes Rec. R. Soc., 1962, 17: 198-206; idem, John Locke (1632-1704), physician and philosopher. A medical biography, London, Wellcome Historical Medical Library, 1963, ch. 1; Guy Meynell, 'Locke,
Boyle and Peter Stahl', Notes Rec. R. Soc., 1995, 49: 185-92; and Patrick Romanell, John Locke and medicine: a new key to Locke, New York, Prometheus Books, 1984.

${ }^{31}$ A R and M B Hall (eds), The correspondence of Henry Oldenburg, 13 vols, Madison and Milwaukee, University of Wisconsin Press, and London, Mansell and Taylor \& Francis, 1965-83, vol. 3, pp. 532-3. Cf. ibid., vol. 2, pp. 521, 570, showing that he intended to include material in the new edition on preserving bodily substances and on the effects of poisons.

${ }^{32}$ Medical material is, however, to be found in Boyle's collections of observations, etc., from the 1660 s, e.g. BP 27, fols. 5-150. 


\section{Boyle versus the Galenists}

\section{Boyle's Suppressed Polemic: its Content and Rationale}

Its scope is most clearly indicated by a synopsis of its main arguments of which two, slightly different, copies survive. The earlier of these, which is printed as Appendix 1, is in the distinctive hand of a scribe whom Boyle appears to have employed towards the end of the period when he lived at Oxford: dated letters and other documents in this hand span the years 1664 to $1668 .^{33}$ That the synopsis was being composed or revised at the time when this version was drafted is clear from the presence of various deletions made in the course of composition. In its format, the document is similar to synopses of other works dating from the mid-1660s, for instance the latter part of The usefulness of natural philosophy, ${ }^{34}$ and there seems no doubt that Boyle intended to write a treatise along the lines indicated by the synopsis, fleshed out by the illustrative material there tantalisingly indicated. The further implication is that it was intended for publication, since there is no evidence that it was meant only for private circulation. ${ }^{35}$

The second copy is much later: it is in the hand of Robin Bacon, who worked for Boyle from the 1670s onwards. Its date is suggested by its context, since it is juxtaposed with the list of "Heads" for Boyle's Memoirs for the natural history of humane blood, which was published in 1684 , having been prepared for publication over the previous few years. ${ }^{36}$ Unlike the earlier version, this has no alterations made during composition, suggesting that it is a copy of a text written previously. In content, it differs from the earlier version in two main respects (the wording of the title is also slightly different). First, it is more spare: whereas the earlier version supplements the main headings by giving details of the data that Boyle was going to bring to bear to make his case, this limits itself to the heads themselves; it also omits the introductory section summarized in the earlier draftpresumably because Boyle saw this as tangential to its main thrust-and goes straight to the main points of the treatise. On the other hand, this version differs from the earlier one in including two extra headings, presumably added after the earlier one had been compiled, since there is no evidence that that is incomplete ${ }^{37}$ In view of the fact that it seems to supersede the other in terms of ground covered, this version will be quoted here: ${ }^{38}$

${ }^{33}$ Hand E: see Michael Hunter, Letters and papers of Robert Boyle, Bethesda, University Publications of America, 1992, pp. xxxvii-iii.

${ }^{34}$ E.g. BP 26, fols. 193-4.

35 Cf. Kaplan, op. cit., note 3 above, p. 200 n. 18: her view is partly based on a misunderstanding of an earlier recension of the present paper.

${ }^{36}$ BP 18, fol. $48 \mathrm{v}$. This is a folio sheet folded into four parts, and quite soiled, as if carried around in someone's pocket. The "Heads" for Humane blood are on the other side of the sheet, while the upper part of the verso is occupied by a list of heads concerning sense, reason and authority. For Bacon, see Hunter, op. cit., note 33 above, pp. xxxi, xxxiii. On the date of Humane blood, see the forthcoming
'Pickering Masters' Boyle.

37 That the plan of the work did indeed develop is suggested by a reference by Boyle to what is probably this work which will be discussed below, in which he refers to "the last scheme" of his intended work on medicine as if there had been different recensions: Boyle, op. cit., note 1 above, vol. 5, p. 454, and below, pp. 338-9.

${ }^{38}$ All texts published from manuscript sources in this paper are presented according to the rules set out in Michael Hunter, 'How to edit a seventeenthcentury manuscript: principles and practice', The Seventeenth Century, 1995, 10: 277-310. In quotations from texts included in the appendix, insertions and deletions will here be ignored. 
Some Considerations \& Doubts about the Vulgar Method or Practice of Physick

That in different Country's the method of Physick dos' considerably vary.

That the Common Method may be good in some Diseases, and yet not in others.

That Method is build upon artificiall (or particular) indications, and these for the most part, as they are the grounds of Methods are built upon Theoryes which Anatomical, or other Discoveries show to be false, or insufficient.

That the Compleatnes of Method supposes a sufficiency in its Instruments whereas really Physitians have not tooles to answer the Indication[s and $]^{39}$ scopes.

That oftentimes a Disease may proceed from severall causes unknown to the Physitian, or at least not duely consider'd by him, and so may make the method improper or at least inferior to another.

That common Experience shows the languidnes and imperfections of vulgar remedies \& method.

That there are some that follow quite differing methods from that which is receiv'd, and yet cure Diseases a [sic] successfully if not better than those that practice it.

That where specificks are knowne there even formidable Diseases are often successfully cur'd without the help of a method built on Artificial Indications.

That the receiv'd method is not so safe, as men suppose, or as that of cureing by specificks where they may be had.

That whereas method is soe much employ'd in varying Remedies according to the Ages, Constitutions \&c of Patients: If we were well furnish'd with specificks, so much nicety would not be necessary.

That our Methodists have not yet such Philosophical History's of Diseases as are fit to be wish'd and possible to be obtain'd.

That our Methodists have not yet sufficiently examin'd the Materia Medica, nor chalk'd out the possible \& practicable way of discovering genuinenes or adulterations of Drugs \& Medicins whether natural or factitious.

As will be seen, the work was pitched as an aggressive and quite comprehensive assault on established medical practice as epitomized in the concept of the methodus medendi, in other words the core of traditional teaching on health care which still dominated medicine in Boyle's day: Boyle calls this "vulgar" in the sense of "commonplace". ${ }^{40}$ In this text, Boyle abandons the balance that he had attempted to achieve in The usefulness of natural philosophy, instead showing an aggressiveness which is quite at odds with the conciliatory image presented by Barbara Kaplan. It might perhaps be thought that this directness is a reflection of the fact that what we have is simply a list of headings, and that if Boyle had written it up the directness would have disappeared under the weight of his convoluted

\footnotetext{
${ }^{39}$ MS damaged and words supplied from the version in Appendix 1.

${ }^{40}$ Compare Boyle's usage in his Free enquiry into the vulgarly receiv'd notion of nature: see Michael Hunter and Edward B Davis, 'The making of Robert
}

Boyle's Free enquiry into the vulgarly receiv'd notion of nature (1686)', Early Sci. Med., 1996, 1: 204-71, on p. 244. On seventeenth-century views of the methodus medendi, see Boss, op. cit., note 5 above; Bates, op. cit, note 5 above. 


\section{Boyle versus the Galenists}

prose. However, this may be tested by attention to what are evidently two surviving sections of the text of the treatise. These are printed below as Appendices 2 and 3, and the latter, especially, shows that-abnormally-Boyle carried the confrontational tone of the synopsis through into the text as well. ${ }^{41}$

Appendix 2, a document presented as a letter endorsed with a title echoing that of the synopses already cited-'Considerations About the received Galenicall Methodus Medendi' - apparently forms the introduction and may well be contemporaneous with the 1660 s synopsis, though it could be later. ${ }^{42}$ Some of the points it makes are qualificatory prolegomena, concerned with making it clear that, though attacking Galenic principles, Boyle was not advocating pure empiricism, which-now as earlier in Usefulness-he considered equally undesirable. To that extent it might be seen as weakening the force of Boyle's critique. But these points are succinctly stated, and are followed by a robust summary of the essence of his position. In it, he contrasts his own reservations about the received method with the position of those who saw it as "so well grounded, so safe, \& in a word so good" that its "excellency \& compleatness" rendered any input from other sources superfluous. The text ends before Boyle had got very far with his argument: the fact that it breaks off at the top of a page may suggest that it was never completed.

The further surviving section of text, printed in Appendix 3, is even more directly and strongly worded. This is to be found in a notebook which Boyle kept $c$. 1680, and is written in the hand of his amanuensis Hugh Greg. ${ }^{43}$ Since the text is full of corrections and alterations (and is rather hastily written towards the end), it was clearly in process of composition at that time. This lengthy passage takes up one specific theme referred to in the synopsis and elaborates it at length, namely the issue of whether orthodox therapy was in fact as safe-or the alternatives as dangerous - as its protagonists claimed. It is a remarkable document, showing a notable sarcasm in developing its theme, and with typically Boylian instances derived from his and his acquaintances' experience deployed in a highly effective way.

To the argument that such therapy was sanctioned by long usage, Boyle answered that such longevity would be valid if it were matched by success: "But if on the contrary it appear, that it has been oftentimes unable to cure the Patients, $\&$ divers times has made them worse than it found them; I do not think that in such Cases Prescription, how immemorial soever, can be rationally boasted of'. After giving various examples of conditions in which the accepted treatment was harmful rather than beneficial, the text continues-like the 1660 s synopsis-by accusing physicians of exercising undue timidity in acute diseases, when patients "might perhaps have been sav'd by a seasonable \& vigorous, thô hazardous, Attempt: And when in such Cases it is pleaded that the Course

\footnotetext{
${ }^{41}$ Other sections of text that could conceivably be related to the lost work are BP 18, fols. 8-10 (in the hand of Bacon); and BP 38, fol. 14 (in a hand which may be that of Frederic Slare). It is possible that more of the treatise survived in the eighteenth century than is now the case, to judge from notes on Boyle MSS by Henry Miles now in BP 36, fol. 142v, though matters are complicated by overlap between this and later medical treatises by Boyle, on which see below.
}

\footnotetext{
42 It is in a scribal hand. That it dates from the $1660 \mathrm{~s}$ is suggested by the appearance of passages apparently in the same hand in the collection of data from that period in BP 27, fols. 5-150. However, its retrospective tone could suggest a later date. Evidence of alteration shows that composition was in process in the draft we have.

${ }^{43}$ Hunter, op. cit., note 33 above, pp. xxix, xxxi-ii.
} 


\section{Michael Hunter}

which was taken was safe; it may be answer'd, that it was so indeed for the Physician, but not for the Patient: the former loosing little or no reputation, whilst the latter looses his life". Echoing a concern for the indigent seen both in The usefulness of natural philosophy and in the collection of recipes that he prepared in his later years, ${ }^{44}$ Boyle wrote: "When a poor Patient lyes sick of a dangerous Disease, the aim of his recourse to a Physician is, to be cur'd by him, or at lest to be reliev'd. But if he desir'd no more than that the Physician should do him no hurt, his surest course were not to send to a Physician at all; For then he need not fear to be killd by him".

More generally, Boyle was critical of the supposed safeness of the so-called "Generous Remedies" of the methodus medendi, particularly bleeding and purging, which "are sure to weaken or discompose when they are imploy'd but do not certainly cure afterwards". Here, Boyle invoked the "comparative" argument mentioned in his synopsis, pointing out that bleeding was not used in China: indeed, he noted how "the most part of the Chymists of differing Sects agree in this, that the Blood is the Balsom of Life, \& that 'tis dangerous to deprive a Patient of it, unless perhaps in some extraordinary \& very urgent Cases". Hence, though he acknowledged that there were circumstances in which bleeding and purging could be valuable, he illustrated the ease with which such practices were overdone by citing the case of a doctor who killed himself by excessive phlebotomy, also instancing the harmful side-effects of commonly used emetics and purgatives, particularly if given to patients "for whose Natures they are unfit".

It is worth pausing at this point to assess the significance of this text. In terms of its content, there is much overlap between the projected work and Usefulness, which deals with many of its themes at greater or lesser length. ${ }^{45}$ What is different, however, is the way in which they are treated. In part, this is because this text has as its raison d'être a singleminded critique of Galenic medicine: in Usefulness, by contrast, Boyle's argument was more for open-mindedness on the part of Galenic physicians, a positive condemnation of their practices being never more than implicit. Equally significant is the contrast with the manner in which the argument is put even in such passages in Usefulness as overlap with the subject matter of 'Some Considerations \& Doubts', since the treatment there is anecdotal and discursive, lacking the edge of the later work.

Take, for instance, the account of the excessive languidness of the so-called generous remedies in Appendix 3 below, and compare the equivalent passage in Usefulness. Boyle is here much more direct than he had been earlier: though Usefulness includes a sarcastic aside about how patients "had not rather be methodically killed, than empirically cured", this forms part of a more digressive passage which lacks the bite of the suppressed work. ${ }^{46}$ By contrast, 'Some Considerations \& Doubts' has a real power, as befits its polemical

\footnotetext{
${ }^{44}$ See Hunter, op. cit., note 17 above, esp. pp. 256-7.

45 E.g. Boyle, op. cit., note 1 above, vol. 2, pp. 85f. on poisons (cf. also BP 18, fols. 8-9, and Boyle, op. cit., note 1 above, vol. 5 , pp. 79, 82-3), 161f. on non-European medical practice (cf. BP 18, fol. 10), 185 on disagreements among doctors, 193 on the need for medicine to take account of new
}

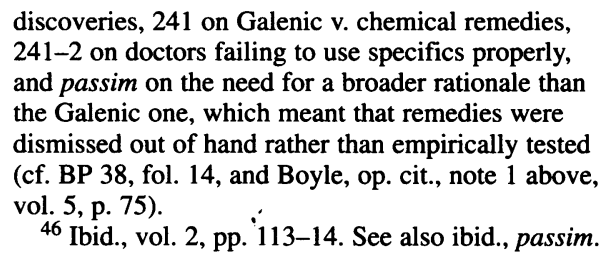




\section{Boyle versus the Galenists}

purpose. Even when dealing with as complex a matter as the differing circumstances in which forebearance from bleeding might or might not be beneficial, it makes far less of an attempt at balance than had comparable sections of Usefulness. Indeed, its directness arguably has something in common with the texts that Boyle wrote at the climax of his "literary" phase in the late 1640s, before he turned to science and discovered the fascination with particulars which often wreaks havoc on his mature style. ${ }^{47}$ Abnormally, here the mature Boyle speaks with real passion, evidently because he felt strongly that medicine was an area where tough action was needed to overcome inbred obfuscation for the benefit of his fellow men. In this text we have, not just a lost work by Boyle, but a different type of work from most of his mature treatises, more aggressively concerned with the world of affairs, and less preoccupied by intellectual issues.

\section{Boyle's Alternative Stratagems and his Later Medical Writings}

As already noted, the notebook in which this passage of text was composed or revised dates from $c .1680 .{ }^{48}$ That Boyle saw the work as current in 1677 is implied by the inclusion in a list made by Henry Oldenburg of "such papers, as were mentioned to me by the Honourable Robert Boyle March 26 1677" of "The Heads of some Considerations and Proposals, towards the promoting the Physiological and Pathological parts of Physick"; this list also contains a separate item, "The Heads of an Essay tending to the improvement of the Materia Medica", which might relate to the parallel compilation on medical science which Boyle appeared to refer to in his letter to Oldenburg of 27 October 1667 and to Boyle's later publications in the area. ${ }^{49} \mathrm{~A}$ further 'Catalogue of the Honourable $\mathrm{Mr}$ Boyle's Writings unpublish'd taken the 7th of July 1684', on the other hand, fails to include the first of these, though it presumably echoes the second in referring to an item 'Of Chymical \& Mechanical Examen of Materia Medica especially by the way of Colours', to the significance of which we will return. ${ }^{50}$ Then, it was in 1685 that Boyle published the statement about the suppression of his work on the doctor's "art" that was quoted at the start of this paper. It therefore seems to have been around 1680 that Boyle first returned to work on a treatise begun in the 1660 s and then decided to abandon it.

A further hint concerning the work's fortunes is provided by the passage about the suppression of his critique of medical practice in Experimenta \& observationes physica. Having explained how he allowed himself to be diverted to other studies, Boyle went on to recount how his discarded papers were seen by Oldenburg (d. 5 Sept. 1677), who, "wonderfully solicitous" as always that useful information should not be lost, prevailed on Boyle to incorporate material from it into the compendium which was ultimately published in the form of Experimenta \& observationes physica. This statement indicates

\footnotetext{
47 See Lawrence Principe, 'Virtuous romance and romantic virtuoso: the shaping of Robert Boyle's literary style', J. Hist. Ideas, 1995, 56: 377-97; Michael Hunter, 'How Boyle became a scientist', Hist. Sci., 1995, 33: 59-103, esp. pp. 62, 69, 73.

48 It is worth noting a possible echo of the work's theme in the preface to Boyle's Experiments and notes about the producibleness of chymical
}

principles (1680), where he noted of the physician's art how, "being conversant about the health and life of man, doctrinal errors in it cannot but be dangerous, and therefore fit, as much as is possible, to be solicitously avoided, or removed". Boyle, op. cit, note 1 above, vol. 1, pp. 587-8.

${ }^{49}$ BP 36, fol. 88.

${ }^{50}$ BP 36, fols. 59-60. 
a link between at least some of the subject matter of the intended book and Boyle's later publications on related subjects, though it is not entirely clear how it should be interpreted. Boyle may have meant that Oldenburg urged him not to abandon the work, hence initially stimulating him to return to it in its own right, and thus explaining its inclusion in the list of papers made in March 1677. This would also be compatible with the evidence from the section of text printed as Appendix 3 that it was composed $c$. 1680. Thereafter, however, he may have decided to abandon it once again, but, recalling Oldenburg's words, resolved not to let its data go to waste. On the other hand, though the implication of Boyle's remarks is that it was the remnants of his attack on medical practice that Oldenburg stimulated him to save by incorporating them into Experimenta \& observationes physica, in fact the medical material that does appear in that book does not tally particularly closely with the headings of the suppressed treatise; rather, it seems likely that it derived from the parallel work on anatomical and medicinal matters. ${ }^{51}$

In any case, within this section of Experimenta \& observationes physica, Boyle provides an alternative account of the origin of the medical material in the book, which may be elucidated by related references among Boyle's unpublished papers. He apologized for including this material, explaining

that when hereafter there shall occur any thing among these Experimenta \& Observationes Physica, that directly relates to the physician's art, you may not think it strange, remembring upon what account I ventured to meddle with things of that nature, and also that you may readily understand what I mean, when you meet with any particulars delivered, as thoughts, or desiderata, or wishes, tending to, or aiming at the improvement of medicine; which however slight or superfluous soever they may be to experienced masters, to whom I did not presume to recommend them, I thought might probably be serviceable to a very ingenious, but yet young cultivator of that noble art, (whose name I concealed, after the way of the curious of Germany, under that of Trallianus) for whose use they were intended.

Moreover, at least one passage in the subsequent text does appear to be addressed to the figure in question. ${ }^{52}$

Let us elucidate this. What we evidently have is a further stratagem on Boyle's part. It seems as if, on deciding to abandon the idea of publishing a reformist treatise on medicine himself, he thought he might overcome the problem of professional demarcation that he gave as one of the reasons for his decision to suppress the book by providing a young doctor with materials from which a work advocating improvements in medical practice might be written on his behalf. Unfortunately, the identity of this figure is obscured by Boyle's use of an assumed name for him, "in imitation" (as he explained elsewhere) "of those that are from time to time given to Physicians \& other Members by the Learned \& fruitful society erected lately in Germany under the Title of Academia naturae curiosorum". ${ }^{53}$ The name used, "Trallianus", probably alludes to one of the famous

\footnotetext{
${ }^{51}$ See Boyle, op. cit., note 1 above, vol. 5, pp. $583 f$.

52 Ibid., vol. 5, pp. 583-4, 591. A draft for the first part of this passage survives in Royal Society MS (hereafter MS) 198, fol. 11.
}

\footnotetext{
${ }^{53}$ MS 189 , fols. $59 v-60$. After Learned, Soci has been deleted, as has the before Academia (which has been altered from Academy) and of the curious after it.
} 


\section{Boyle versus the Galenists}

doctors of classical antiquity who hailed from Tralles, Lydia-Alexander (sixth century $\mathrm{AD}$ ) or Thessalus (first century AD), the latter the founder of Methodism. One possible candidate is a man who had a close relationship with Boyle in his later years, David Abercromby, a physician of Scottish extraction who translated various of Boyle's books into Latin. ${ }^{54}$ However, it could equally easily be some other young physician whose links with Boyle are not otherwise documented. ${ }^{55}$

More to the point is a further document, which can only be a draft of a covering letter for the materials there referred to. This survives in a notebook of $c .1680$, and its text is as follows: ${ }^{56}$

Sir You will now receive a Paper that I dare not any longer withhold from you, as unworthy as it is to be presented to you. I presume, you may $<$ yet $>$ remember ${ }^{57}$ what you have been made acquainted with, about the Reasons that induc'd me to desist from the Design I once had, of making ample Additions to that Section of the Usefulness of Experimental Philosophy that treats of Medicinal Subjects. And therefore, not to remind you of the Discouragements I had from prosecuting my <Intention>, ${ }^{58}$ I shall now need only to add, That the same Reasons induc'd me many years ago, to throw aside what I had written by way of Enlargement of that Discourse. So that now I hope so Indulgent a Peruser <as your self> will rather excuse than wonder, that to comply with his Curiosity I /fol. 19v/ presume to tender him a ${ }^{59}$ Bundle of little more than bare Wishes \& Proposals, towards the Improvement of the Physitians Art: these being but a Rapsody, chiefly afforded me by some old \& long forgotten Notes, which had the luck to survive their lost Companions: And which, having long thought them lost, I recover'd too late to be able to put them into a better $<\&$ more coherent $>$ form: ${ }^{60}$ thô in that wherein your Curiosity \& my Hast makes them now appear, I can scarce hope $<$ they $>^{61}$ should do more than afford some hints to $<$ you \& such other $>^{62}$ sagacious <persons as $>$ despise nothing that may any way conduce to the Improvement of ${ }^{63}<$ a very noble $>$ usefull, but not yet <a very > perfect, Art./fol. 20/

To give you now a summary account of the $<$ chief $>$ things that ${ }^{64}$ partly $<$ were $>$ design'd to be treated of, $\&^{65}$ partly <were> deliver'd, in reference to the Physiological, Pathological, and Therapeutical parts of the Medicinal Art.

${ }^{54}$ See E B Davis, 'The anonymous works of Robert Boyle and the Reasons why a Protestant should not turn Papist (1687)', J. Hist. Ideas, 1994, 55: 611-29. Abercromby's medical works were collected as Opuscula medica tractenus edita, London, for Samuel Smith, 1687, but none of them seems to represent collaboration with Boyle. I am grateful to Vivian Nutton for his advice on the significance of the name "Trallianus".

55 Potential candidates could conceivably include the authors of various works on medical topics dedicated or addressed to Boyle: see Fulton, op. cit., note 28 above, pp. 164-6, 179.

${ }^{56}$ MS 198, fols. 19-20. Hand: Hugh Greg. Endorsed T[ranscri]b'd.

${ }^{57}$ Followed by by deleted. A further deletion follows what: considerable [?]

${ }^{58}$ Replacing former [?: altered from first] Design, deleted. Three lines previously, there is a mark for an insertion before making ample, but no insertion.

${ }^{59}$ Followed by Company of Fragments, as drawn for the deleted.

${ }^{60}$ Followed by the following deleted passage (deleted up to the illegible word separately from the rest): \& fill up the Gaps that were obvious [illeg.] and compleat them by the addition of such [replacing furt[her?] deleted] Instances as might make them contribute somewhat [altered from something] not altogether inconsiderable to the Improvement of the Medicinal Art.

${ }^{61}$ Replacing I deleted.

62 Replacing those deleted. Within the insertion, you is altered from yourself. Two words later, persons as replaces Physitians that deleted.

${ }^{63}$ Followed by an excellent but a deleted and replaced by an illegible deleted word: what?

64 Followed by were deleted.

65 Followed by were inserted and deleted. 
At this point the manuscript unfortunately ends. (In passing, it is worth drawing attention to the extreme difficulty that Boyle had in drafting the last sentence in the first paragraph, which is symptomatic of the somewhat hesitant tone of the document as a whole). However, some further fragments referring to materials provided for Trallianus throw more light on the matter, particularly one surviving in a notebook dating from the last years of Boyle's life. This states: ${ }^{66}$

The particulars I <have elsewhere $>^{67}$ mentiond $<$ my self $>$ to have propos'd towards the Improvement of Physick to $a^{68}$ ingenious yonge <Doctor> whom I call Trallianus, <were $>$ of 2 sorts. The former did more directly \& nearly concern the practise of Physick. And the Latter consisted of such <hints or advises> as thô more remotely \& less directly tending to Practise, did yet seem to conduce to the inabling a Physician to ${ }^{69}$ increase his knowledg \& dexterity, \& thereby improve his art.

Proposers [sic] of the 1 st $<$ order $>^{70}$ belong not to this place, where I shal for speciall reasons content my self to refer without much <regard to method $>^{71}$ or $<$ coherence $>$ the things that occur to me about the later sort of Proposals or Advises <some of them to one \& som to another> of the ensuing Heads.

Unfortunately, at this point this draft, too, ends. What is crucial about it, however, is the clarity with which it distinguishes between two sections of the materials offered to Trallianus, one which "did more directly \& nearly concern the practise of Physick", which is presumably to be identified as 'Some Considerations \& Doubts', and the other material "more remotely \& less directly tending to Practise", which is perhaps to be linked to the papers relating to anatomy and medication referred to in Boyle's letter to Oldenburg of 17 October 1667 and the inventories of 1677 and 1684. Further light on the second section is provided by yet another list of "the things by me suggested or recommended to Trallianus" which survives and which need not be transcribed here since it has already been published by Barbara Kaplan (though she fails to comment on the fact that it is addressed to Trallianus, and hence its connection with the other documents noted here). ${ }^{72}$ What is interesting is that this tends to confirm the link between the more "scientific" part of Boyle's agenda for Trallianus and the research that Boyle had done in the 1660s, including the material on human blood, urine and other bodily fluids that Boyle had executed in conjunction with Locke and others; in addition, "The Chymico-mechanical Examen, or History, of several Aliments, whether Solid or Liquid" there referred to could relate to the papers on the materia medica listed in the inventories.

What is equally significant is that we seem here to have a kind of missing link with

\footnotetext{
${ }^{66}$ MS 187, fols. 105v-6. Hand: Bacon. Endorsed $T$ [ranscri]b[e]d at start and $h$ at end.

${ }^{67}$ Replacing mention [?] deleted; the next word altered from mention.

${ }^{68}$ Altered from $a$ and followed by yonge $P h$ deleted. Three words later, Doctor replaces Physician deleted, and five words after that were replaces are deleted.

${ }^{69}$ Followed by improve deleted. Earlier in the sentence, inabling a Physician was marked for
}

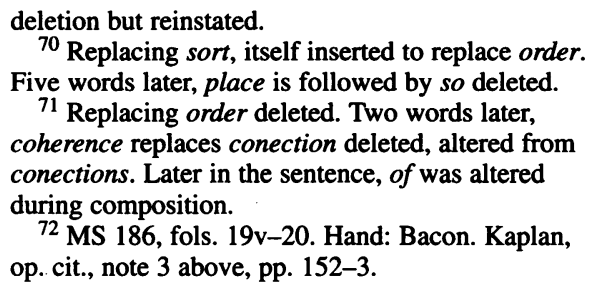




\section{Boyle versus the Galenists}

various of the treatises on medical science which Boyle was to publish in the later years of his life: thus material on the blood and other fluids materialized as Boyle's Memoirs for the natural history of humane blood (1684), while at least part of his treatment of the materia medica was to come out as Medicina hydrostatica (1690). What is more, although both his notes for Trallianus and the inventory of 1677 distinguish between Boyle's attack on orthodox medicine and his more general notes, the fact that in the former they are seen as "two sorts" of proposals for the same end, namely "the Improvement of Physick", suggests that Boyle saw the two as interconnected. Indeed, though potentially separable, they evidently to some extent overlapped. This is borne out by the inclusion of a section on the materia medica in the second (though not the first) of Boyle's synopses of 'Some Considerations \& Doubts'. It would also help to explain his apparent conflation of the two in his comments about the source of the medical material in Experimenta \& observationes physica. ${ }^{73}$ That Boyle perceived a link between his more scientific medical material and his attack on orthodox medical practice may additionally be suggested by the juxtaposition on a single sheet of a synopsis of his controversial work with the heads for his Memoirs for the natural history of humane blood. ${ }^{74}$ Equally revealing is certain evidence relating to Boyle's Medicina hydrostatica, which it is worth outlining here.

As already noted, the subject matter of Medicina hydrostatica clearly echoes one of the topics in the later version of the headings of 'Some Considerations \& Doubts', namely that "our Methodists" had failed properly to examine the materia medica, and in particular that they had not investigated means "of discovering genuinenes or adulterations of Drugs \& Medicins whether natural or factitious". It was to this that Medicina hydrostatica was devoted, illustrating the value of knowledge of the specific gravity of substances precisely for this purpose. Interestingly, Boyle also planned a sequel, the theme of which was specified in the 1684 inventory: this would have been entitled Medicina chromatica and would similarly have illustrated the value of colour tests. ${ }^{75}$ Indeed, what is apparently a draft introduction to this work echoes the apologies we have already encountered in explaining how it was "but a part of a much larger Discourse about <things> relating to the materia medica that I had design'd \& more than begun", his plans for which had been thwarted by "Cross Accidents". 76

What is more, it seems likely that Boyle had the idea of including a postscript in the published version of Medicina hydrostatica which would have given some information about the abortive larger work of which it was originally intended to form a part, but that at the last minute he changed his mind. As a result, the preface tantalisingly refers to an inclusion that is not in fact present. In the preface, Boyle explained how the essay was

in my first intention, but a large fragment of a greater work: whereof an account is given in the letter to a friend, (that is premised to a paper annexed to the following essay) which (letter) having been

${ }^{73}$ Boyle, op. cit., note 1 above, vol. 5, p. 583.

74 See above.

75 See above, n. 50. See also Boyle, op. cit., note 1 above, vol. 4 , p. 454 . The intended second volume of Medicina hydrostatica would have combined this with material on the materia medica more generally: see esp. BP 27, p. 385 and MS 186, fols. 54f., 85v, $180,183$.

${ }^{76}$ MS 186, fol. 84v-5 (after Discourse, of deleted). Note also MS 199, fol. 131, a further covering note of $c .1680$ to material "about the Examen \& Improvement of the Materia medica", which "Chance or (which is more likely) Fraud, lately rob'd me of" and which he had therefore had to reconstruct from drafts and fragments. It is conceivable that this is the lost medical work also referred to in Boyle, op. cit., note 1 above, vol. 5, p. 39. 
intended for a kind of preface to the last scheme of the whole larger scheme, if the reader please to peruse it, he will there find the rise and scope of this little tract, as well as of the other parts of that designed book. ${ }^{77}$

When the reader turns to the end of the work, however, he finds a postscript explaining that "When I began to send the essay, called Medicina Hydrostatica, to the press, and drew up the foregoing preface to it, I intended it should, in the same book or volume, be accompanied by another help or two, to explore and improve the Materia Medica". But he went on to state that, in fact, he found that the length of the volume meant that to have added what he originally intended would have made it "a mis-shapen book, and inconvenient to be opened", "wherefore it seemed expedient to divide the whole intended work into two volumes or tomes". ${ }^{78}$ Since no second volume was ever published, it is impossible to be sure what the letter giving details of the intended larger work, including its "scheme", comprised. It is quite conceivable, however, that it was a covering letter to a synopsis of 'Some Considerations \& Doubts' like those printed above and in Appendix 1.79

Some of the material in Medicina hydrostatica - as in Humane blood-could easily have been presented in a more aggressively anti-Galenic manner, matching the tone of the section of the suppressed book printed in Appendix 3. In fact, however, it is not. A R Hall long ago observed the contrast between the moderate tone of these medical works published by Boyle in his later years and that of The usefulness of natural philosophy: whereas in Usefulness "Boyle showed a rather nonchalant inclination to criticize unspecified physicians for excessive narrowness or caution", now he "found it easier to tolerate the distinct experience of the physician". 80 The contrast with the suppressed 'Some Considerations \& Doubts' - of the existence of which Hall was unaware-is, as we have seen, more striking still. Now, however, Boyle abandoned such aggressiveness, adopting instead the more conciliatory and reasonable stance that Barbara Kaplan has mistakenly seen as characterizing his approach throughout his life. Humane blood and Medicina hydrostatica also share with Boyle's other principal relevant publication of these years, his Of the reconcileableness of specific medicines to the corpuscular philosophy (1685), the characteristic that they quite self-consciously deal with what might be described as the medical spin-offs of natural philosophy (the same is also true of the medical material included in Experimenta \& observationes physica). Even more than had been the case with Usefulness earlier, they are self-deprecatory about Boyle's role, deferring to doctors' expertise and stressing that his vocation was that of a natural philosopher, an outsider to medical practice. Thus The reconcileableness is aimed at overcoming the view prevalent among medical men that corpuscularianism was incompatible with the specific virtues of medicines, but it is otherwise a kind of appendage to-if not cast-off from-the programme championing mechanistic explanations against scholastic ones to which a number of Boyle's natural philosophical treatises belong. ${ }^{81}$ Medicina hydrostatica also illustrates the medical spin-offs of Boyle's

${ }^{77}$ Ibid., vol. 5, p. 454.

78 Ibid., vol. 5, p. 507.

${ }^{79}$ A less likely alternative is that the reference is to the material referred to in note 76.

${ }^{80}$ A R Hall, 'Medicine and the Royal Society', in
A G Debus (ed.), Medicine in seventeenth-century England, Berkeley and Los Angeles, University of California Press, 1974, p. 430.

${ }^{81}$ Cf. Boyle, op. cit., note 1 above, vol. 5, esp. pp. 76-7. 


\section{Boyle versus the Galenists}

more general scientific programme, and Humane blood is even more overt in its natural philosophical, as against medical, orientation, though Boyle again made it clear that it had important potential implications for medicine. ${ }^{82}$

The only exception to this are Boyle's writings on the preparation of medicines, namely the various versions of the prefatory material to his collection of Medicinal experiments (many of them unpublished) and the Discourse about the advantages of the use of simple medicines annexed to The reconcileableness. These continue to display in more or less extreme form the hostility towards orthodox medical practice to which Boyle had given voice in the suppressed 'Some Considerations \& Doubts', though it is significant that his strongest statement of hostility to the medical profession-in the unpublished preface to his 'Medical Prescriptions communicated to Robert Boyle', most of which now survives only in a Latin translation-was never published. ${ }^{83}$ Undoubtedly Boyle continued to harbour strong views on such subjects. But he thought better of a direct attack for reasons that we must now explore.

\section{Boyle's Reasons for Suppressing 'Some Considerations \& Doubts' and the Relations between Science and Medicine}

The principal reason that Boyle gave for his decision to abandon his attack on orthodox medical practice in his published statements about the matter was the hostility of physicians. This issue of demarcation therefore needs to be considered in its own right. It is also important because Boyle's statements of the tensions he experienced on this score are at odds with the views of various authors who have used his relations with professional groups whose expertise overlapped with natural philosophy to illustrate what they perceive as a carefully-formulated intellectual strategy on Boyle's part. Thus John Harwood has written how "by systematically cultivating a persona that included the attributes of 'gentleman', 'layman', and 'virtuoso', he could justify his writing on theological topics (though not a divine) and on medical subjects (though not a physician)", while in A social history of truth Steven Shapin has gone even further, asserting how: "Tied to no one profession, Boyle might credibly contribute to any of them. The Christian virtuoso was situated everywhere and nowhere in professional space". 84

It is true that, as Harwood and Shapin claim (echoing similar views on the part of Barbara Kaplan), Boyle sometimes made statements which appeared to invoke his ambivalent status as a non-physician with medical interests as giving him a certain power, enabling him to comment on the field without suffering any disadvantages from direct participation in it. As he put it in Humane blood, "my present task does not require, that I should write like, what I am not, a professed physician, but like what I endeavour to be, a

\footnotetext{
82 Ibid., vol. 4, esp. pp. 595-7.

${ }^{83}$ See Hunter, op. cit., note 17 above.

84 John Harwood, 'Science writing and writing science: Boyle and rhetorical theory', in Hunter (ed.), op. cit., note 4 above, 37-56, esp. p. 42; Shapin, op.
}

cit. note 7 above, p. 182. Cf. ibid, ch. 4 passim. See also Steven Shapin and Simon Schaffer, Leviathan and the air-pump: Hobbes, Boyle, and the experimental life, Princeton University Press, 1985, esp. pp. 72f, and above, note 6. 


\section{Michael Hunter}

diligent natural historian", and in Experimenta \& observationes physica he was even more explicit:

natural philosophy being a science of far greater extent than physic, and supplying it with many of its principles and theories, it is very possible, that naturalists, though not professed physicians, may propose some such comprehensive notions and methods, as may awaken and enlarge the minds of them that are so, and at least afford some useful hints to considering and ingenious men. ${ }^{85}$

If this may seem up-beat, however, other comments show Boyle's awareness that the fact that he was not a professional doctor placed him at a disadvantage: indeed, this is suggested even by the ancillary references that Shapin cites at the relevant point in his study, though he appears not to perceive the conflict between them and the line he there takes. ${ }^{86}$ There were two reasons for Boyle's disquiet. One was that he might legitimately feel that doctors had a discrete professional sphere that deserved respect and from which he was excluded. As he put it most tellingly in Humane blood, "Having resided for many years last past in a place so well furnished with learned physicians as London is, I was careful to decline the occasions of entrenching upon their profession". ${ }^{87}$ The same point comes across equally strongly in the passage quoted at the start of this paper in which he stated that he suppressed his polemic when he discovered that some doctors were "not well pleased, that a person not of their profession should offer to meddle with it, though with a design of advancing it". Interestingly, the draft version phrases this even more strongly: "it would be unwelcom to some, whom I had no disposition to contend with that their Art should be as they would be thought to judge, invaded by a Person that was not of their profession". 88

Apart from the significance of such demarcation in its own right, the fact that Boyle was not a professional doctor meant that he lacked opportunities which physicians had. Concerning the study of human blood he thus complained how "being no professed physician, I had not the opportunities of examining that of sick persons molested with particular diseases, (which yet would much conduce to a complete history of the blood)", elsewhere commenting on the difference between physicians and "I, whose condition exempted me from taking upon me their calling, and who conseqently must want many opportunities, that others enjoyed, of making observations about the phænomena of diseases and of medicines", 89

${ }^{85}$ Boyle, op. cit., note 1 above, vol. 4, p. 644, vol. 5 , p. 583.

${ }^{86}$ Shapin, op. cit., note 7 above, pp. $180-1$ and notes.

${ }^{87}$ Boyle, op. cit., note 1 above, vol. 4, p. 637.

88 Ibid., vol. 5, p. 583; BP 36, fol. 12. See above, pp. 323-4.

${ }^{89}$ Boyle, op. cit., note 1 above, vol. 4, p. 596, vol. 5 , p. 583 . See also his response to $\mathrm{Mr} \mathrm{H}$ concerning recipes supposedly plagiarised from Monsieur $L S$, BP 36, fols. 7-8, where he writes: "living in a place so well stock'd with Learned Physicians as is London, I had small opportunity to try the things he presented me" (see Hunter, op. cit., note 17 above, p. 265). It is perhaps worth noting that, both in the second quotation in the text and in Usefulness (see above, p. 326), Boyle claims that his aristocratic status precluded his making medicine his profession: however, though it is true that it was unusual for early modern aristocrats to practise medicine other than in a purely amateur way, doctoring being essentially an occupation for those of "middling" status, I am not aware of any mandate enforcing this: an analogue to Boyle is provided by Henry Pierrepoint, Marquess of Dorchester (see Cook, op. cit., note 5 above, pp. 119, 144). 


\section{Boyle versus the Galenists}

As these remarks show, there was a negative side to the demarcation which has hitherto been overlooked, suggesting that Boyle was less of a self-conscious strategist in such matters than an evaluation like Shapin's implies. ${ }^{90}$ Rather, he was forced to make the best of a situation which was not altogether as he wished. Both the evidence about the suppression of his own book and the convoluted stratagem involving "Trallianus" that has been outlined here reveal that issues of demeanour and demarcation had a significant restrictive effect on Boyle, inhibiting him from making public strongly-held views which he thought might have been of widespread public benefit.

Yet what is paradoxical is that Boyle had expressed similar views in Usefulness: his comments there about the fact that he was not a professional physician similarly range from the ambivalent to the negative, as where he noted how the "more critical and severer sort of readers" might think it "impertinent for me, who do not profess to be a physician, to treat prolixly of matters medicinal". 91 Yet this had not dissuaded him from the mild barbs against orthodox practice to be found in that work, or the direct assault represented by its sequel.

The same is true of a related argument that one would have expected to weigh heavily with as conscientious a man as Boyle, namely that the sheer complexity of medical issues made it difficult to lay down the law on such matters. As he explained in his essay on Simple medicines, "I am as sensible as another of the almost insuperable difficulty of making any certain experiments in physick"; hence he warned that too much reliance should not be placed on the medicines that he advocated "till they have been more competently tried, than perhaps some of them, for want of opportunity, have been; and administered to patients of differing complexions, ages, and other circumstances". 92 Yet, here again, he had already made a similar point in Usefulness, where he wrote: "as I do not set down medicinal experiments with the same positiveness, that I do physiological ones, so I do not intend to venture the repute of being a faithful relater of experiments, upon the success of any medicinal receipt or process". ${ }^{93}$ Indeed, it was to the views on the difficulty of guaranteeing the invariable efficacy of cures that he had expressed in Usefulness that he recommended his readers in Simple medicines. ${ }^{94}$ Some sense of the complexity of such matters is even in evidence in the more polemical 'Some Considerations \& Doubts'. Yet when he conceived that work he clearly felt that there were sufficient home truths to be delivered about the inadequacies of Galenic medicine to overcome such scruples on his part, and he evidently still felt this way when he composed the extant section of text of $c$. 1680 which is published as Appendix 3.

\footnotetext{
90 I should perhaps add that, in my view, Shapin's portrait of Boyle represents a schematic construct which bears little resemblance to what Boyle was really like. For documentation of the troubled side to Boyle's character, which Shapin ignores, see Michael Hunter, 'Alchemy, magic and moralism in the thought of Robert Boyle', Br. J. Hist, Sci., 1990, 23: 387-410; idem, 'Casuistry in action: Robert Boyle's confessional interviews with Gilbert Burnet and Edward Stillingfleet, 1691', J. Ecclesiastical Hist., 1993, 44: 80-98; and idem, 'The conscience of Robert Boyle: functionalism, "dysfunctionalism" and the task of historical understanding', in J V Field and
}

F A J L James (eds), Renaissance and revolution: humanists, scholars, craftsmen and natural philosophers in early modern Europe, Cambridge University Press, 1993. See also Hunter, op. cit., note 1 above, esp. pp. lxiii-lxxix, and Hunter, op. cit., note 17 above.

${ }^{91}$ Boyle, op. cit., note 1 above, vol. 2, p. 199. Cf. pp. 66, 201, 240 and passim.

92 Ibid., vol. 5, pp. 115-16.

93 Ibid., vol. 2,, p. 240 . Cf. ibid., pp. 242-4, passim.

94 Ibid., vol. 5, p. 129. 


\section{Michael Hunter}

Hence we need an explanation which focuses on Boyle in the early 1680s. Why might he have become more reticent about taking an overtly polemical stance at that point than had been the case earlier? One event which had occurred soon after his first bout of activity on 'Some Considerations \& Doubts' was his move from Oxford to London. It is interesting how he singles out London as a place especially replete with learned physicians in the passage cited on p. 341, and undoubtedly the London College of Physicians made its professional status more "visible" than was the case elsewhere in the country. Boyle's move to London might well have induced second thoughts about a polemic begun in Oxford, in a milieu where his collaboration with medical men on physiological research might have insulated him against anxieties which later came to the fore. These would have been further intensified by the hostility between the College of Physicians and the Royal Society which reached its peak at the time of Henry Stubbe's polemics against the Society in the years around $1670 .{ }^{95}$

By the end of that decade, these polemics had subsided, which might explain why Boyle returned to work on the book at that point. But the London medical community remained a source of potential disquiet, and matters were further complicated by the revival of the regulatory activity of the College of Physicians in the 1670 s and 1680 s, in the rather reactionary political climate of those years, in contrast to the more relaxed state of affairs that had prevailed since the Interregnum. ${ }^{96}$ This had the effect of accentuating the polarisation between "learned" and "empirical" physic, and hence of making Boyle's attack on Galenic physicians appear to ally him more closely with their empirical rivals than he might have liked.

In addition, Boyle might have noted the mixed reception in medical circles of the books giving closely-observed accounts of illnesses and their treatment which were published in these years by his neighbour in Pall Mall, Thomas Sydenham, notably his Observationes medicae of 1676 (though it is perhaps worth noting that Boyle nowhere explicitly refers to Sydenham in his own writings). ${ }^{97}$ Such considerations might have reinforced a sense on Boyle's part-even as he went back to work on the text-that matters were more complicated than his outspoken attack on the accepted practice of physic implied. He may also have been aware that the methodus medendi was itself changing to a greater extent than his frontal assault on it acknowledged. ${ }^{98}$ Moreover, he may increasingly have come to feel that, for all his reservations about about Galenic principles, it was problematic that he could not offer a complete alternative system as against a series of piecemeal expedients for medical change.

A further factor relates to Boyle's overall personal and intellectual evolution. Though he had always been self-conscious about his writings and had been in the forefront of attempts to guard against plagiarism as early as the $1660 \mathrm{~s}$, there is clear evidence of his

\footnotetext{
95 See Cook, op. cit., note 23 above; idem, op. cit., note 5 above, ch. 4; Michael Hunter, Science and society in restoration England, Cambridge University Press, 1981, ch. 6. See also above p. 327.

${ }^{96}$ Cook, op. cit., note 5 above, pp. $192 \mathrm{f}$.

${ }^{97}$ See G G Meynell (ed.), Thomas Sydenham's 'Observationes medicae' (1676) and his 'Medical
}

observations', Folkestone, Winterdown Books, 1991. See also Dewhurst, op. cit., note 30 above, pp. $30 \mathrm{ff}$. and passim, and King, op. cit., note 2 above, pp. 113-58.

98 See Boss, op. cit., note 5 above; Bates, op. cit., note 5 above. 


\section{Boyle versus the Galenists}

becoming more defensive about his books in the late 1670 s and early 1680 s. $^{99}$ It is possibly also significant that, just at this time, he was opening up an attack on medicine on another front, namely in his Free enquiry into the vulgarly receiv'd notion of nature (1686). This work was initially composed in the mid-1660s, but Boyle revised it extensively c. 1680 , and study of extant draft material for the work shows that a disproportionate number of the additions to it made at that time dealt with the reification of "nature" in a medical context, which Boyle saw as theologically and philosophically undesirable, and which he therefore sought to undermine. Since Boyle seems to have perceived his assault on this commonly accepted notion as a bold one, this may have acted as a disincentive to open up another front by publishing an attack on medical practice as well (it is possibly significant that $A$ free enquiry includes a further apology for encroaching on "the physician's peculiar province"). 100

If these are speculations based on broader considerations, can anything useful be learnt from further manuscript evidence relating to the suppressed work? In fact, three such documents survive from $c .1680$ or later which have not yet been referred to. These seem to express a more guarded view than the texts so far quoted and printed in the Appendix; they may thus provide a clue to the way in which Boyle's views were changing at this critical time.

The first, which survives in the same notebook as the section of text printed below as Appendix 3, opens with the words: "The summary of my opinion about the receiv'd method \& practis of Phisick may be briefly comprisd in these particulars". This makes it sound as if it is going to recapitulate 'Some Considerations \& Doubts', but in fact its content is significantly different. It continues as follows: ${ }^{101}$

1. The vulgar practis of Phisick especialy where tis almost merely Galenical, is on ${ }^{102}$ more accounts than one, Imperfect.

2. Physitians therefore ought seriously \& industriously to endeavour by growing improvements to compleat it ${ }^{103}$

3. For this reason they ought not lightly to reject or condemn the Hypotheses or ${ }^{104}$ Methods of others especialy those which ${ }^{105}$ either nations or societys appove [sic] if they $<$ be $>$ grounded upon reason or favour'd by considerable experiments.

4. Upon the same account Physitians ought ${ }^{106}$ to take in as much help as they can, <even> from the observations, $\&$ <experiments $>^{107}$ of those Empericks, which though otherwise

\footnotetext{
${ }^{99}$ See Hunter, op. cit., note 17 above, pp. 263-5; Hunter and Davis, op. cit., note 40 above, esp. pp. 217-18.

100 Boyle, op. cit., note 1 above, vol. 5, pp. 159, 215 and 158-254 passim. See also Hunter and Davis, op. cit., note 40 above, esp. pp. 258-60.

${ }^{101}$ MS 199, fol. 44. Hand A. Endorsed in margin at start $\operatorname{Tr}$ [anscribe]d and crossed through in pencil. Some of the alterations and insertions are made in pencil.
}

\footnotetext{
102 Altered from one.

103 Apparently rewritten from endeavour to improve \& compleat it.

104 Followed by Prac[tices] or deleted.

105 Altered from when [?], followed by either deleted (and preceded by a small deletion). In the following line, the insertion of $b e$ is in pencil, and grounded is apparently altered from something else.

106 Followed by not deleted.

${ }^{107}$ Replacing competently tryd remedys deleted.
} 


\section{Michael Hunter}

<either> illiterate or unskilfull have some remedys for this or that disease that are ${ }^{108}$ recommended by succesfull /verso/ tryals.

5. That for the same reason Physitians do not <by > persecution, or <severe penaltys, too $>$ much discourage the posessors of approved remedys; especially if they be ${ }^{109}$ innocent $\&$ specifick, from makeing use of them against those particular distempers for which they have bin often found effectual.

6. But that men unlearned or otherwise not duely qualified, ought to confine themselves, or be confind by others <to administer ${ }^{110}$ Physick in those diseases onely wherin they have such special \& well try'd remedys; \& ought not to presume to practis Physick in All diseases indifferently as authorized Physitians $<$ do \& may \& that particularly they be very shy of tampering with Fevers>

7. For generaly speaking, a learned Doctor, though unasisted with Chymical Arcana, has $<$ in most cases $>$ great advantages ${ }^{111}$ to help the sick, in comparison of a mere Emperick, whether he be illiterate or not.

As will be seen, though this interesting document opens with a robust summary of the themes of Boyle's suppressed polemic, it then moves to other points which had not appeared there. One of these, no. 5, is quite new, having appeared neither in 'Some Considerations \& Doubts' nor in The usefulness of natural philosophy. It may well reflect Boyle's concern at the revival of the regulatory activity of the College of Physicians which has already been referred to: indeed, this passage might even be taken as suggesting that this was a factor encouraging Boyle to return to the book for his second bout of work on it at this time. More significant, however, are the final two points, since these display an ambivalence absent from 'Some Considerations \& Doubts', reverting to the kind of attempted balance between the virtues of learned and empirical practice that had been in evidence in Usefulness, and perhaps indicating the direction in which Boyle's mind was moving at this time.

Two further documents are interesting, partly because they echo this, and partly because they show a special concern about Boyle's reputation. In the latter regard, they have something in common with the opening paragraph of the introduction to 'Some Considerations \& Doubts' printed in Appendix 2: indeed, though that may date from the $1660 \mathrm{~s}$, it could be later, hence explaining its somewhat retrospective and slightly apologetic tone. It lays particular stress on the need to protect Boyle's reputation by helping the person to whom it is addressed "to discern, how far you may or may not, give credit to what is talk'd of about my opinions of the common Methodus Medendi".

The two further texts definitely date from Boyle's later years, and both express similar concerns. One is a fragment in one of the notebooks that Boyle kept in the last years of

\footnotetext{
108 Followed by competently deleted. A $p$ has been deleted between the $m s$ in recommend.

${ }^{109}$ Followed by safe \& deleted.

110 Replacing from practising deleted; administer altered from administering. Two words later, in is followed by $o$ deleted. The next word, those, is
}

altered from something else. Earlier in the sentence, duely has an $e$ deleted before the $u$. The insertion at the end of this paragraph is in pencil.

${ }^{111}$ Followed by to practis Physick deleted. The next word, to, is followed by so [?] deleted. 
his life, and it represents the opening lines only of a further apologia. ${ }^{112}$ It reads:

I have long observ'd that there is a notion intertain'd by the Generality of Chymists, \& severall physitians too, that Experience has perswaded me to $\langle\text { be }\rangle^{113}$ prejudiciall to the Medicinall Art; \& very much so to the poorer sort of patients. For there are many $<$ who ${ }^{114}$ presume

(The comment about the poor is puzzling. In fact, Boyle thought that orthodox medicine did insufficient to help the poor; ${ }^{115}$ hence either he was imputing to his critics a very caricatured view of his opinions, or the passage is garbled, with some words omitted before "to the poorer sort"- "for its failure to help", for instance. Either way, this may explain why Boyle abandoned the draft so quickly.)

Lastly, we have a further incomplete letter, this time in the hands of two amanuenses who worked for Boyle from the late 1670 s until the end of his life. This reads as follows: 116

\section{Sir,}

Doubting that your friend Dr N.N. may be one of those, to whom I have of late been represented as a Person unfriendly to Physitians in generall, and to their Profession; my concerne for the opinion of a learned man, of whom I have so good a one, ingages me to desire you, to set me right in his thoughts; if you find that endeavours have been us' $d$ to give him ill impressions of me. 'Tis true that I looke upon the Art of Physick, as I doe upon all others ${ }^{117}$ that depend upon Naturall Phylosophy, as parts of knowledg that are not yet perfect but capable of improvements: since the Art of Medicine borrows most of its Principles from Physicks; which it selfe, as 'tis wont to be taught \& received, I take to be as yet a science defective enough; in comparison of the ${ }^{118}$ certainty \& extent, that may reasonably be desired in it, \& possibly will hereafter be attain'd by it. But, thô I thinke the Theories \& Methods vulgarly receiv'd among Physitians, to be neither unquestionable nor perfect, yet I desire you will let Dr N. know, ${ }^{119}$ that, if I thought I had not sufficiently <clear'd my self $>^{120}$ in Writings already publish'd, I could here ${ }^{121}$ convince him, that I am neither a Despiser nor a Maligner of his Profession, nor of those that Practise it; but have a great Esteem for the former, \& not only an <high $>$ Esteem, but a <personal $>$ Kindness, for $<$ severall $>^{122}$ of the latter. 'Tis true, that I am not forward to reject an Experienc'd Remedy, because it $^{123}$ either $<w a s>$ Devis'd, or <is $>$ too much Extoll'd, by an Illiterate Empyric; \& that I think it <very > possible, that <a Doctor ${ }^{124}$ may be a great Scholar, without being a great Physician; \& on the Contrary, a Man may have a very Usefull Receipt, without being able to draw it up in Modish Form, and may ${ }^{125}$ cure a Particular Disease, without being able to speak Latine. But notwithstanding all /fol. 137/ this I am ${ }^{126}$ far from thinking, that every Illiterate Man, that brags of $\left\langle\right.$ or has $>^{127}$ a rare Receipt, or a Chymicall Processe, is $^{128}$ in reference to the General Practise of Physic, worthy to be, I say not prefer' $d^{129}$ to, but made

112 MS 187, fol. 4v. Hand: Greg.

113 Replacing think deleted.

114 Replacing that deleted.

115 See Hunter, op. cit., note 17 above, pp. 255-8.

116 BP 37, fols. 136-7 (written in the hands of

Robert Bacon and Hugh Greg). It is marked $T$ [ranscri]bd in the margin, and the whole is crossed through in pencil. At the start, Sir is written twice.

117 Followed by a deleted comma.

118 Replacing $a$ deleted.

119 At this point, the handwriting of the document changes from that of Bacon to that of Greg.

120 Replacing done it deleted.

121 Followed by give, altered to showe [?] and deleted; could is possibly altered from would.

122 Replacing many deleted.

123 Followed by was deleted. Three words earlier, Experienced was altered from something else during composition.

${ }^{124}$ Replacing one [?] deleted; the previous word, that, is altered from something else. Five words later, Scholar, is followed by a deleted letter.

125 Followed by with it deleted.

126 Followed by so deleted.

127 Replacing <\& really possesses $>$ [?] deleted.

128 Followed by fit to be deleted.

129 Followed by before deleted. Three words later, made altered from make [?]. 


\section{Michael Hunter}

equal to, a Learned \& Rational Physician, thô not yet furnish'd with the higher Arcana of Chymistry. And, to let you see that I say not this either Complementally or Inconsiderately, I will, if you please to afford me a little of your Patience, acquaint you with the ${ }^{130}$ Reasons that induc'd me to be of the Opinion I have now express'd.

It seems than [sic] to me, that a worthy Physician, by which I mean a Rational, ${ }^{131}$ Honest, Learned \& Experienc'd Man, thô he be no Secretist, has severall Advantages for the successfull Practise of Physic <in its full ${ }^{132}$ extent $>$ above a <meer $>$ Emperick, thô we suppose <him an honest Man, not Irrational, nor altogether Illiterate, nor Unexperienced; and ${ }^{133}$ also furnish'd with a considerable $>134$ number of choice Receipts.

At this point the draft breaks off. Yet the extant portion has some interesting themes, in many ways recapitulating the dilemma that Boyle faced in deciding what to do about his opinions on medicine. Like the texts previously cited, it suggests that Boyle was concerned about the reputation that he had acquired for being hostile to doctors. Its heavy stress on the dependence of medicine on natural philosophy echoes the treatises of the $1680 \mathrm{~s}$ referred to in the last section (as also, of course, The usefulness of natural philosophy). It also bears some similarity to the stance that Boyle had adopted in Usefulness in that, although it contains some barbed comments about the relative merits of empirics and learned doctors (which, taken out of context, could be taken to illustrate his hostility to learned physic), it is almost self-effacing concerning Boyle's perception of the imperfections of the methodus medendi. It also hastens to reassure the recipient of Boyle's personal esteem for many doctors, a further factor discouraging him from a frontal assault on their profession. Indeed, though it breaks off too soon to be sure of this, the implication is that it was going to be mainly devoted to illustrating Boyle's positive evaluation of the medical establishment.

These documents leave one in no doubt that Boyle found the whole issue a difficult one. On the one hand, he was aware of the defects of the received methodus medendi; he must also have been aware of the power that a frontal attack on it from as influential a man as him would have had: the almost fawning use of his work by Marchamont Nedham in the 1660 s cannot have left him in any doubt about this. ${ }^{135}$ On the other hand, Boyle must also

\footnotetext{
130 Followed by Grounds deleted. Five words later, to is followed by think deleted. Two words after that, of is followed by the opin... Minde deleted.

${ }^{131}$ Comma replaces \& deleted.

132 Replacing <in his full $>$ deleted. Three words later, $a$ is followed by meer [?] deleted (at end of line).

${ }^{133}$ Replacing \& [?] deleted. Earlier in sentence, nor altered from not.

${ }^{134}$ Inserted in margin (repeating him and considerable, which left in text), replacing <an honest \& not Irrational> furnish'd with a considerable Number of considerable Receipts neither Irrational nor illiterate And also deleted.

135 See above, p. 326. In this connection it is worth noting a further episode in which both
}

Nedham and Boyle were involved. Richard Gower's English translation of Sylvius' A new idea of the practice of physic, London, for Brabazon Aylmer, 1675 , is dedicated to Boyle (sigs. b3v-4); it also has a promotional 'To the Reader' by Marchamont Nedham, which he claims that he wrote at the prompting of an unnamed "Gentleman" who, from Nedham's description of him, could very well be Boyle: "Should I name that Learned Person, there is none of the most stiff Philosophers of the Time, but would perhaps bow the Head at the bare mention of his Name" (sig. b4v). On the other hand, matters are complicated in this case by Boyle's hostility to the acid-alcali theory which Sylvius espoused: see Marie Boas, 'Acid and alkali in seventeenth-century chemistry', Arch. Int. Hist. Sci., 1956, 34: 13-28. 


\section{Boyle versus the Galenists}

have been acutely aware of the damage that an outspoken attack by him could have done to a learned profession for many of whose members he had considerable respect. Above all, Boyle was scrupulously concerned to be fair. At the end of the day, his scrupulousness made him a bad polemicist. The powerful but somewhat one-sided view of orthodox therapy given by the documents printed in the Appendices undoubtedly reflects one face of Boyle's ideas; but, in the end, it was only the more ambivalent view seen in his published writings that he felt able to print.

Hence, the new material presented in this paper should help us to achieve a better understanding both of Boyle and of his role in relation to the medical practice of his day. In the first place, we see that the persona of natural philosopher that he adopted in contradistinction to the role of a professional doctor was not quite as serene as such authors as Steven Shapin make it appear. In fact, Boyle's relations with the medical profession were ambivalent and problematic for him. Indeed, here we see a further aspect of the troubled Boyle that I have depicted in other writings, which in my view makes better sense of the evidence from this sphere of his activities as from others. ${ }^{136}$ Equally important, this material illustrates that Boyle's career as a medical writer is less straightforward than is depicted by Barbara Kaplan. In fact, the self-consciously distanced stance that Boyle presented in his medical publications of the 1680 s grew out of an intermediate phase when he considered an aggressive line that he felt unable to sustain. This is all the more poignant because of Kaplan's conclusion that Boyle's impact was more limited than it might have been partly because of his failure to express his views more robustly. ${ }^{137}$ Ironically, as the unexpectedly sharp tone of the documents presented here shows, Boyle himself would have agreed with her evaluation that a more direct approach was required. Yet we understand Boyle better for learning that, characteristically, he could not bring himself to publish so one-sided a view of the issues involved and hence suppressed it.

${ }^{136}$ See above, note 90.

${ }^{137}$ Kaplan, op. cit., note 3 above, pp. 167f., esp. 172-3. 


\author{
APPENDIX 1 \\ "Long" version of Boyle's synopsis of his critique \\ of orthodox medical practice, in hand $E^{\mathrm{a}}$ (BP 18, fols. 133-4) \\ Considerations \& Doubts \\ Touching the Vulgar Method \\ of Physick
}

The Introduction admonishing;

That it were absurd \& therefore is not intended to reject or depreciate method in generall, which is but the use of reason applyd to Physick

That neither doe I intend to reject any mans particular Method, since I know not what it is, \& therefore cannot say but that as it differs from the Common it may be better then it, But about the Common Method <as tis calld $>$ I considerd

That in differing Countrys it varys considerably as not only the method in China, Cochin, Japayn $\& c^{1}$ differs from the European, but here in Europe the French \& English practise differ as in bleeding in the small pox \& Use of Antimonyates \&c $<\&$ indeed the practise only fit[?] sometimes to vary according to ${ }^{2}$ Climats \& Constitutions $>$

That the Common Method ${ }^{3}$ may be good in some deseases tho not in others: $\&$ there is <great> difference to be made betwixt the [practice?] of bare method in acute $\&$ in Chronicall Deseases.

That Method is build [sic] upon Indications, ${ }^{4} \&<$ those $>$ for the most part, as they are the grounds of method, upon Theorys which Anatomicall $<\&$ other $>$ Discoverys show to be false \& Insufficient witnes the Doct[rine] of Digestions ${ }^{5}$ Catarrhs \&c

That the compleatnes of Method supposes a sufficiency in its Instruments, whereas really Physitians have not tooles to answer their Indications \& scopes in ${ }^{6}$ many sick Bodys where there is greatest need of them, as they have not constant menses moventia, nor constant sanguina sistentia, nor suppurantia, nor Disentientia, /fol. 133v/ nor Diureticks in

\footnotetext{
a I.e., dating from $c$. 1664-8: see Michael Hunter, Letters and papers of Robert Boyle, Bethesda, University Publications of America, 1992, pp. xxxvii-iii. The document is a bifoliate; the verso of

${ }^{1}$ Followed by but deleted.

2 Followed by the deleted.

${ }^{3}$ Marked for deletion but reinstated.

${ }^{4}$ Followed by <scheeres[?]> deleted; that deleted
}

fol. 134 is blank. The first two paragraphs seem to comprise the introduction, with the main text following thereafter: cf. above, p. 330.

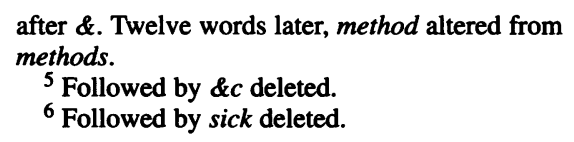




\section{Boyle versus the Galenists}

Dropsys, nor Calculum frangentia, nor in some Cases soe much as sudorifick much lesse Alexipharmicæ in the Plague \& other Malignant Deseases. ${ }^{7}$

That oftentimes a Desease may proceede from severall Causes unknowne to the Physitian or at least unheeded ${ }^{8}$ by him. And a Medicine ineffectuall when the desease proceeds from one cause may be proper $\&$ successfull when it proceeds from another. And also a desease may soe depend upon the Conjunction of severall causes That by destroying ${ }^{9}$ any one of those, \& consequently by severall way[s], it may be cur'd: soe that a Medicine or Method that may seeme Improper upon supposition $<$ that the received Theory $>^{10}$ is compleat \& adæquate may yet upon another account be rational [?] \& effectual. And in regard of the forementiond Incompetency of ${ }^{11}$ Vulgar Remedys to deserve the Title that are given them: It may be <sometimes> adviseable to chuse another method then the vulgar ev'n ${ }^{12}$ where that in itselfe is the best, because wee have some ${ }^{13}$ powerfull Menstruum that will answer our scope in this deviating method \& none that will doe it in the Common. Illustrations \& Examples to this purpose, particularly in ${ }^{14}$ the practice of Chyrurgions, who often discusse, what they ${ }^{15}$ would but cannot suppurate, \& in curing dropsys by other ${ }^{16}$ evacuations especially vomits for want of other efficatory Diureticks.

That common experience show the Languidnesse ${ }^{17}$ \& Imperfections of the Vulgar remedys \& method, there being noe <internall $>$ desease that a wary Physitian dare with them only undertake certainly to cure except a recent Gonorhæa. /fol. 134/ for thô in many other cases men dye not of but ware out the desease: yet it dos not sufficiently appear that they are curd by the Physitian

That there are some that follow quite differing methods from that which is receivd \& cure $\mathrm{D}$ [is]eases every whit as s[ucc]essfully if not better, \& that not by spec[ifi]ck[s] but by ${ }^{18}$ method, the $\mathrm{m}[$ edic]ines being but ordinary. Examples to Confirme this

That where specificks are knowne there deseases very formidable are successfully cured without the help of a method build [sic] on Artificiall Indications which Gallen $<\&$ Sennartus $>^{b}$ themselves ${ }^{19}$ confesse not to take place in such cases namely in the ${ }^{20}$ wounds

b Daniel Sennert (1572-1637), a leading

German medical writer who tried to reconcile

\footnotetext{
${ }^{7}$ Followed by And therefore deleted.

8 Followed by $a$ deleted.

${ }^{9}$ Followed by on [?] deleted. Six words later, consequently is followed by may deleted.

${ }^{10}$ Followed by of th.. deleted. Later in the sentence, effectual is preceded by es.

${ }^{11}$ Followed by $R e$... deleted. Five words later, the is followed by en [?] deleted.

12 Followed by when [?] the deleted. Five words later, is is followed by expressed deleted. Two words after that, because [?] is deleted after best.

13 Followed by powf deleted. Four words later, will is followed by assur deleted. Two words after that, doubts is deleted after our.

${ }^{14}$ particularly in replaced by $<$ whereto perhaps
}

modern theories with Galenism.

may be referred $>$ but then marked for reinstatement.

15 Followed by need [?] deleted. In the previous

line, $s[?]$ deleted before Chyrurgions.

${ }^{16}$ Followed by Exapor [?] deleted.

${ }^{17}$ Followed by of deleted. Two lines down, with has been altered from something else.

${ }^{18}$ Followed by $a$ new deleted. The letters in square brackets here are obscured by damage to the manuscript.

${ }^{19}$ Altered from himself after insertion of Sennertus' name; confesse at the same time altered from confesses. Adjacent to this passage there is a cross in the margin.

${ }^{20}$ Followed by storis [?] deleted. 


\title{
Michael Hunter
}

of scorpions vipers, mad Dogs \& in other deseases springing from poisons.

That the receivd method is not soe safe as men suppose, or as that of Curing by specificks where they may be had both because the received method dos in desperate $\&$ difficult cases suffer patients to dye that by more vigorous attempts might be rescued $\&^{21}$ also because whereas specificks for the most part alter not the body unlesse it $\mathrm{be}^{22}$ in some distemper which they are proper for, $\&$ soe if they doe not cure, they at least doe litle or noe harme, the Vulgar method is such that in most cases if the physitian aime wrong or misse his stroack he dos mischiefe. For not to mention that long courses ev'n of vehemently altering medicines, where they are not proper may doe much harme, bleeding \& purging \& vomiting \& in some Constitutions sweating, if they be not skillfully \& Judiciously imployd must doe mischiefe both upon other scores \& upon that manifest one of weakning the patient.

That whereas method is soe much imployd in varying remedys according to Ages Constitutions \&c. If wee were well furnishd with specificks soe much nicety would not be necessary, as may be seene in the oyle of scorpions, which universally cures the biting of that venomous creature, \& in the arcanum ad Hydrophobium of Palusorus which Testimony is very considerable $\&$ to be annexed.

\section{APPENDIX 2}

\section{Introduction to Boyle's critique of orthodox medical practice, in the form of a letter} (BP 38, fols. 111-12) ${ }^{23}$

\author{
Considerations \\ About the received Galenicall \\ Methodus Medendi
}

Sir,

Since you are willing to be assisted to discern, how far you may or may not, give credit to what is talk'd of about my opinions of the common Methodus Medendi, I conceive my selfe obliged to acquaint you with some of my thoughts about that subject as I set them down some years since for my owne remembrance. And I the rather make use of these Notes because by doing so, I may at once both let you see with what freedom \& openness I deal with you \& comply with my owne hast which would not permit me to trouble you with a prolix Discourse on this subject. ${ }^{24}$

\footnotetext{
${ }^{21}$ Followed by be deleted. There is a cross in the margin adjacent to this passage.

${ }^{22}$ Followed by distemperd deleted.

23 Unknown hand. The whole has been crossed through in ink. The title is in pencil; it is very faint,
}

and may deliberately have been erased. Sir is written twice.

${ }^{24}$ Followed by But before deleted. Earlier in this sentence, make is altered from made. 


\section{Boyle versus the Galenists}

But before I proceed to the mention of particulars, it $<$ will $>^{25}$ be requisite to premise 2 or 3 advertisements to obviate mistakes.

And first as it will be easily beleiv'd <that I am $>^{26}$ not so $<$ extravagant $>^{27}$ as to be an Enemy to <a> Methodus Medendi in generall; for that being but an exercise of Reason apply'd to the Therapeuticall part of Physick, it would be unreasonable to reject it: And he cannot but be unfit to be ${ }^{28}$ a Physitian \& consequently entrusted with such precious things as the Lives of men, that would practise Physick without acting upon grounds, \& for ends that to him appear rationall, \& will ${ }^{29}$ neglect the observing of order \& discretion in the administring of his Remedies[.] He that $<$ neglects $>^{30}$ to make the best use of his reason on such occasions is unworthy ${ }^{31}$ to practise <up>on rationall Creatures /fol. 111v/ \& scarce deserves to $\mathrm{be}^{32}$ a Farrier much less to be allow'd to be a Physitian.

In the next place Sir; I pretend not to censure the Methodus Med[endi] of this or that particular person; for ${ }^{33}$ there may be many such methods that I am not acquainted with, \& consequently am not qualify'd to speak of, $\&$ in such a free $\&$ inquisitive age as this besides that I am sure that there are divers ${ }^{34}<$ peculiar $>$ methods employ'd by this or that Physitian that ${ }^{35}$ exceedingly differ from one another, I cannot doubt but that there <may be $>^{36}$ some raisd $\&$ perspicacious Witts whose methods may be as well better than the vulgar as differing from it.

3 rdly ${ }^{37}$ And I consider too, that thô the receiv'd, as they call it, methodus medendi be commonly lookt upon as one entire doctrine; yet since 'tis conversant about ${ }^{38}$ Diseases that are very differing there may be no necessity either to approve it, or $<$ to ${ }^{39}$ condemn it universally \& without distinction: It being very possible that that part of the vulgar method which for Instance belongs to Plurisies may be Good \& Commendable; \& yet that which belongs to some other Diseases may be defective \& censurable.

The state then of the Controversy which has been sometimes disputed of, or rather debated between some of your Learned Freinds \& me, will be best gather'd out of the occasion of our debates For they maintain'd that the $<$ vulgarly $>$ receivd $<$ Practise $>40$ of Physick /fol. $112 /$ as it has been $<\&$ is $>$ commonly taught in those Schools that professedly follow ${ }^{41}$ the

\footnotetext{
${ }^{25}$ Replacing would deleted. Earlier in the sentence, proceed was altered from proceeded in the course of composition.

${ }^{26}$ Replacing \& deleted.

${ }^{27}$ Replacing unreasonable deleted. Two words later, to is followed by dis deleted. Five words after that, $a$ replaces the deleted.

${ }^{28}$ Followed by entrusted with deleted, following $a$, also deleted.

${ }^{29}$ Followed by not deleted. The next word, neglect, is followed by to observe <such> an order in the administration deleted.

${ }^{30}$ Replacing omitteth [?], itself replacing denyes.

31 Duplicated by unfit to be allowd but marked for reinstatement. Two words later, practise is followed by Physick deleted.
}

\footnotetext{
32 Followed by allow'd deleted. At the start of the page, nor deleted.

${ }^{33}$ Followed by besides that deleted.

34 Followed by par deleted.

35 Followed by $v a$ deleted.

${ }^{36}$ Replacing are deleted. There is a further small deletion three words earlier, after doubt.

${ }^{37}$ Followed by Nor do I thinke fit ne [ither] deleted.

${ }^{38}$ Followed by very deleted.

${ }^{39}$ Replacing two [?] deleted. Earlier in the sentence, a character is deleted before necessity. Four words later $\&$ is accidentally repeated.

${ }^{40}$ Replacing Method deleted.

${ }^{41}$ Followed by Gale[n] the Greek \& deleted. Two words later, Doctrine is followed by of the deleted.
} 


\section{Michael Hunter}

Doctrine \& Prescriptions of the Greek \& Arabian Galenists \& is thô with some variety \& Innovation embraced by ${ }^{42}$ Fernelius $^{c} \&$ others, whose <Institutions $>$ are wont to be read in the Modern Schools: these methods ${ }^{43}$ say $<$ they $>$ ev'n as they are applyd to particular Diseases are so well grounded, so safe, $\&$ in a word so good, that ${ }^{44}$ those that practise $<$ Physick> against them, or without them are commonly ${ }^{45}$ dangerous \& unlearned persons, \& are at least to be lookt upon as Empyricks; whose administrations of Physick are neither Methodicall nor safe. ${ }^{46}$ And to obviate an objection that the Anatomicall Discoveries of the moderns, $\&$ the new medicinall preparations introducd by Chymists $<$ did $><$ as to the former but somewhat ${ }^{47}$ illustrate the Theory of <some $>$ Diseases; \& as to the latter of them but supply the methodists ${ }^{48}$ with some new Pharmaceuticall Instruments; but ought not to alter the methodus med[endi] handed down to us from the Ancients. This ${ }^{49}$ perfection, or if you would rather have me call it so, Compleatness or Excellency of the Methodus Medendi [;this] ${ }^{50}$ notion of this Method[us] Med[endi] which represents it, as a thing so compleat in its kind \& free from Imperfection's did I confess ${ }^{51}$ seem to me to <ascribe $>$ too much of excellency \& compleatness to it, $<\&>$ to the Vulgar Practice of Physick that is built upon it, which I <was hindred $>^{52}<$ from $>$ fully acquiescing $<$ in $><$ for $>$ divers considerations, some of which I shall subjoin ${ }^{53}$ according to my promise as I formerly registred /fol. 112v/ them for my own remembrance. ${ }^{d}$

c Jean Fernel (1497-1558), French academic physician, whose textbooks, which attempted to update classical medicine, were widely used in the period.

d The rest of the page is blank.
42 Followed by the Generality of the deleted. Five words later, Institutions replaces practicall Institutions deleted.

${ }^{43}$ Followed by $I$ deleted.

${ }^{44}$ Followed by all deleted.

45 Followed by rash \& deleted.

${ }^{46}$ Followed by To which deleted. Six words later, that is followed by was added deleted, after which that is accidentally repeated.

${ }^{47}$ Inserted in the margin, replacing did at best but deleted. Two words later, the is followed by can [?] deleted.

${ }^{48}$ Followed by $P h$ deleted.

${ }^{49}$ Followed by comple deleted. Four words later, you is followed by please deleted. This sentence was crossed through prior to the whole text being crossed through.

${ }^{50}$ Followed by so explan deleted. The bracketed word has been inserted to complete the sense of the passage.

51 Followed by sem [?] deleted. Five words later, ascribe replaces compass [?] deleted. Two words after that, much is followed by to it deleted.

52 Replacing cannot as yet deleted. Four words later, in replaces for the deleted. The next word, following, should also have been deleted but was accidentally left in place in the manuscript.

${ }^{53}$ Followed by as deleted. 


\title{
Boyle versus the Galenists
}

\author{
APPENDIX 3 \\ Fragment of text from Boyle's \\ 'Considerations \& Doubts Touching \\ the Vulgar Method of Physick' \\ (MS 199, fols. 120-114v')
}

There is scarce any thing that has so much confin'd the generality of Physicians to the vulgar Method of Physic, \& kept them from impartially considering the Reasons \& the Practises of those that dissent from it, ${ }^{54}$ as the $<$ Persuasion $>$ they have, that the receiv'd Method is most safe, $\&<a n y>55$ that deviate from it dangerous.

But, thô this ${ }^{56}$ be very generally < believ'd > \& very confidently urg'd, yet I must take the liberty to doubt, whether it be as firmly grounded.

For 1. The Argument upon which this vulgar Opinion leans, seems to me little more than a Supposition. For if you ask, why the receiv'd Method of Physic should be thought very safe? the Answer will be, that it has been generally practis'd for many Ages, \& that even by eminently learned, as well as by ordinary, Physitians. And I frankly confess this were a weighty Argument, if every Method of curing a Disease that has been <imploy'd > long \& generally, ${ }^{57}$ had <been > also imploy'd successfully. But if on the contrary it appear, that it has been oftentimes unable to ${ }^{58}$ cure the Patients, $\&$ divers times has made them worse than it found them; I do not think that in such Cases Prescription, how immemorial soever, can be rationally boasted of. I will not here enter into $\mathrm{a}^{59}$ Discussion of /fol. 119v/ some Questions, that may not be impertinently mov'd, about the Safeness of $<$ divers $>^{60}$ receiv'd Practises in Physic, that perhaps are as well lyable to Exceptions, as those I am going to name. But I shall <for brevitys sake content myself to> take notice of two or three, that by <some of $>$ the most judicious Doctors themselves, are confess'd to be dangerous.

It was very long, \& in divers Places is yet, the Custom of Chirurgeons \& Physicians too, to ${ }^{61}$ attempt the cure of the Erysipelas, by the application of cooling \& repelling Medicines to the Part affected, even at the beginning. And yet the learned \& judicious Sennertus ${ }^{\mathrm{f}}$ acknowledges this to be, tho a common, yet a very unsafe Practise, by which

e I.e., in reverse order, since Boyle was writing from the back of the book towards the middle. These leaves also show an old pencil pagination, pp. 74-85.

\author{
Hand: Greg. \\ ${ }^{f}$ See above, note b.
}

\footnotetext{
54 Followed by those [?] deleted. Three words later, Persuasion replaces Belief deleted.

55 Replacing those deleted.

56 Followed by Opinion deleted. Four words later, believ'd replaces imbrac'd deleted.

${ }^{57}$ Followed by imployd deleted.
}

\footnotetext{
58 Followed by a deleted word: dive[rs?] Four words later, \& is followed by sometime [s] deleted. ${ }^{59}$ Altered from an and followed by Inquiry deleted.

${ }^{60}$ Replacing some deleted.

610 altered from something else.
} 


\section{Michael Hunter}

the Peccant \& very ill condition'd matter being driven inwards, has divers times expos'd the Patient to ${ }^{62}$ very bad Symptomes, $\&$ perhaps far more dangerous than the Erysipelas it self.

So in Rheumatisms the famous \& experienc'd Riverius confesses, that the common Practise of Physicians, to give Purging \& Sweating Medicines at the beginning, does but exagitate or exasperate the peccant Humour, \& instead of curing increase the Distemper. ${ }^{\mathrm{g}}$ And he observes that in <the> same Disease, if Paregorical Medicins be, as is usual, administred before the Declination, they fixe the Humour, \& make the Disease more obstinate. $^{63}$

And, since a Patient may be destroy'd, not only by the positive Uses of a ${ }^{64}$ bad /fol. $119 /$ Medicine or Method, but by the unskilfull forebearance of the $<$ most $>$ proper Remedyes ${ }^{65}$ I cannot but observe, that for many Ages the generall Practise of Physitians has been very faulty, in reference to Teeming Women. For till ${ }^{66}$ within an Age or two, an over great Reverence for an either false or misunderstood Aphorism of Hippocrates, made Physicians superstitiously ${ }^{67}$ forebear Bleeding Women with Child, even in such Cases ${ }^{68}$ where Phlebotomy was plainly Indicated, \& where perhaps there was little probability, that the $<$ Patient ${ }^{69}$ could be sav'd by the $<$ usual $>^{70}$ Helps. ${ }^{\text {h }}$ And I think there are now few Doctors that doubt, that thousands of $<$ big belly'd $>^{71}$ Women have been $<$ happily $>$ preserv'd \& made Mothers, by Phlebotomy judiciously imploy'd, $<$ who $>^{72}$ would otherwise in probability have been lost, together with ${ }^{73}$ their unborn Babes. $<$ Now since within an Age or two at furthest $>,{ }^{74}$ the three above mention'd Practises, that are now acknowledg'd to be dangerous or hurtfull, could be justifyed by the same Argument that is now so confidently urg'd, namely that they had been long \& generally receiv'd; $I^{75}$ cannot look upon the Commonness of a Method, thô perhaps <countenanced ${ }^{76}$ by its Antiquity too, as a Demonstration of its being /fol. 118v/ safe, unless it be grounded upon <some> solid Reason, or recommended by considerable success.

When a poor Patient lyes ${ }^{77}$ sick of a dangerous Disease, $<$ the aim of $>^{78}$ his recourse to a Physician is, to be cur'd by him, or at lest [sic] to be reliev'd. But if he desir'd no more

g See Lazarus Rivière, The practice of physick, London, Peter Cole, 1655, pp. 547f. Paregorical

62 Followed by great deleted.

63 Followed by And deleted.

64 Followed by <all> Remedy or Med deleted.

65 Followed by especially if it be deleted.

${ }^{66}$ Followed by in these deleted.

${ }^{67}$ Followed by afraide deleted. The next word, forebear, is followed by an illegible deletion: sweat [?].

${ }^{68}$ Followed by <as> of a Plethoric habit of Body, or deleted.

${ }^{69}$ Replacing Phys itself replacing Patient.

${ }^{70}$ Replacing other deleted. The next word, Helps, is followed by that were deleted.

${ }^{71}$ Replacing teeming deleted. Four words later, happily replaces happily [?] deleted.

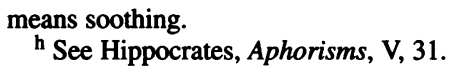

\footnotetext{
72 Replacing an illegible deleted word: such [?]. The next word, would, is followed by a deleted word: not [?].

${ }^{73}$ Followed by the Carelayey [?] deleted.

74 Replacing And yet an Age or two ago deleted.

75 Followed by seeme greate $R e$. [sic] shall allow my self the liberty deleted: i.e., representing more than one stratum of revision. Four words later, the is followed by urg' $d$ [?] deleted.

${ }^{76}$ Replacing recommended deleted.

77 Followed by dang deleted.

${ }^{78}$ Replacing a deleted inserted word, which itself replaces his; the next word, his, has been altered from has.
} 
than that the Physician should <do him no hurt $>,{ }^{79}$ his $<$ surest $>$ course were not to send to $^{80}$ a Physician at all; For then he ${ }^{81}$ need not fear to be killd by him. Indeed in many Chronical Distempers, where the Disease will inducias ferre, ${ }^{\mathrm{i}}$ tis safer to be too $^{82}$ slow \& cautious, than too venturous. But in divers Acute Diseases, $\&$ <in severall> others too ${ }^{83}$ where the Case is almost desperate, a timid Course may be more dangerous than a venturous one. For, as twas judiciouly said by Celsus in reference to such occasions, satius est anceps experiri remedium quam nullum,j $\&^{84}$ Hippocrates in the very beginning of his

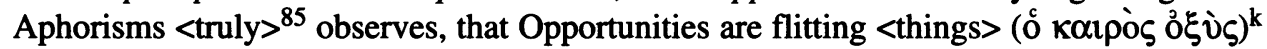
which the overcautious delayes of a timid Physician having once suffer' $d$ to slip, they are too often irrevocably lost, $\&$ with them the Patient, ${ }^{86}$ who might perhaps have been sav'd by a seasonable \& vigorous, thô hazardous, Attempt: ${ }^{87}$ And when in such Cases it is pleaded <that $>$ the Course which ${ }^{88}$ was taken was safe; it may be answer'd, that it was so indeed for the Physician, ${ }^{89}$ but /fol. 118/ not for the Patient: the former loosing little or no reputation, whilst the latter looses his life; \& therefore, to add that upon the by, tho in slighter Sicknesses, Princes, ${ }^{90}$ by reason of the extraordinary attendance $\&$ accomodations their elevated Station commands, have some ${ }^{91}$ advantage <of > ordinary Patients, yet in difficult \& threatning Diseases, I count a Monarchs Case to be more dangerous than a Subjects. For the Physicians <more> considering what their own Safety than the Princes Danger requires, ${ }^{92}$ dare not make use of any uncommon Method or suspected Remedy, thô they well enough see that ordinary ones will not ${ }^{93}$ rescue him, being retain'd, by a perhaps excusable fear of being question'd, from Acting by that Hippocratical Rule, Extremis morbis extrema aptanda sunt Remedia. ${ }^{1}$ And indeed in $<$ deplorable $>$ Cases $^{94}$ the chief difference the Patient finds, between $<$ a very $>95$ timid Physitian \& a bold Empyric, seems to be this, that the latter ventures to kill him, \& the former tamely lets him Dye; thô it be perhaps much more probable, ${ }^{96}$ that a brisk $<$ Remedy $>$ would not destroy him, than that

\footnotetext{
i bring a respite.

$\mathrm{j}$ "It is better to try a doubful remedy than none at all". De medicina, II.10.8

$\mathrm{k}$ "The moment is fleeting". Aphorisms, I, 1.
}

\footnotetext{
${ }^{79}$ Replacing give him no Hurtfull Medicines deleted. Two words later, surest replaces safest deleted. Earlier in the sentence, a character is deleted after desir'd.

${ }^{80}$ Altered from for [?].

${ }^{81}$ Followed by <re > might be sure, the Physician would not kill him deleted.

${ }^{82}$ Followed by <circumspect>, itself replacing slow than [?] deleted.

${ }^{83}$ Followed by an illegible short deletion.

84 Followed by as deleted, and then by the following inserted above the line but deleted again (except for we, evidently left by accident): <we may well apply to such Cases, what I remember $>$. Within this, well is followed by a brief deletion, while there is another at the end: to [?].

${ }^{85}$ Replacing justly deleted. The next word, observes, is followed by ó kalpós deleted.

${ }^{86}$ Followed by to whom it is no less fatal deleted.
}

\footnotetext{
1 "For extreme illnesses extreme remedies should be used". Hippocrates, De fracturis, i. 23 (Littré, iii, 492); quoted by Galen in his commentary on this text, Kühn, xviib, 370.
}

Eight words later, $a$ has a further stroke deleted at the end.

${ }^{87}$ Followed by an illegible deleted word: Here [?].

${ }^{88}$ Replacing that deleted.

${ }^{89}$ Altered from Physicians.

90 Followed by a deleted character.

${ }^{91}$ Followed by little deleted. The next word, advantage, is followed by above deleted. After Patients, there is a cross in the text.

92 Followed by they deleted.

93 Followed by him [?] deleted.

94 Followed by also deleted. Before the beginning of this sentence, But this (as I was saying only upon the by, is deleted.

95 Replacing an illegible word: the [?] After timid, $a$ deleted.

96 Altered from improbable. Four words later, Remedy is followed by will not deleted. 


\section{Michael Hunter}

the languid ordinary ones ${ }^{97}$ /fol. $117 \mathrm{v} /<$ will $>$ cure so <forlorn> a Malady. But these Considerations I readily acknowledge belong but to ${ }^{98}$ dangerous or well nigh desperate Diseases. Wherefore I now proceed to a Reflexion ${ }^{99}$ of a more generall import. ${ }^{\mathrm{m}}$

The main thing that induces me to question the safeness of the vulgar Methodus medendi in many Cases, is the Consideration of the nature of those Helps they usually imploy, \& some of which are honour'd with the Title of Generous Remedies. These Helps are Bleeding, Vomiting, Purging, Sweating, \& Spitting; of which I briefly observe in Generall, that ${ }^{100}$ they <are sure to $>$ weaken or discompose $<$ when they are imploy'd $>{ }^{101}$ but do not certainly cure afterwards.

As for Phlebotomy, when one reads the Encomiums that Authors, especially Modern, do $<$ deservedly> give the Blood, one would expect they should be very sparing of it. ${ }^{102}$ And I have been inform' $d$ both by Books of Voyages, \& by a Learned Man that practis'd Physic in China, that <in $>$ that ${ }^{103}$ populous Countrey the Physicians seldom or never let Blood. And here in Europe the most part of the Chymists of differing Sects agree in this, that the Blood is the Balsom of Life, \& that 'tis dangerous to deprive a Patient of it, unless <perhaps> in some extraordinary \& very urgent Cases. <And ${ }^{104}$ thô I readily acknowledge, that Phlebotomy /fol. $117 /$ is on many occasions usefull, \& in some necessary, <to > those that are not furnish'd with noble Arcana; <and common>105 Experience shows, that many dye of <Inflammatory Distempers such as > Pleurisies, $<$ Peripneumonias \& $>$ Anginas, ${ }^{106}$ who, if they had been seasonably \& sufficiently Blooded, might probably have escap'd: $y$ et 'tis not to be deny' ${ }^{107}$ but that oftentimes Phlebotomy is a dangerous Remedy. For as it proves a generous one when 'tis skillfully imploy'd, so if in those Cases the Physitian aims wrong or misses his Mark, he <usually much $>108$ impairs his Patients condition, \& not seldom <either procures or at lest $>$ hastens his end. And ${ }^{109}$ there are now and then such latent Particularities either in the Disposition of the Patient, or the Nature of the Disease, that renders it far more difficult than most men are aware, to ${ }^{110}$ know when Phlebotomy may be us'd without danger: and one that is heedfull \& impartial may easily observe, ${ }^{111}$ that 'tis not easy to be sure, that he that uses

$\mathrm{m}$ The ink changes at this point, as if the

${ }^{97}$ Followed by will be deleted. Four words later, forlorn replaces desperate deleted; $a$ was also accidentally deleted, but has been retained for the sense.

${ }_{98}$ Followed by such Distempers stubborn deleted.

${ }^{99}$ Followed by which may see [?] be applyed to a far greater num deleted.

100 Followed by the [?] deleted. The inserted phrase that follows they replaces certainly deleted.

101 Replacing whilst they are operating, deleted; in the inserted passage, ad is deleted after are. Five words later, cure is followed by when their operation deleted.

${ }^{102}$ Followed by especially since the Knowledge following text was executed at a fresh session.

\footnotetext{
of its Circulation deleted.

103 Altered from something else: the [?].

104 Replacing But, deleted.

105 Replacing And deleted; the insertion originally read and daily common but daily has been deleted.

106 Followed by \& other Inflamma deleted.

107 Followed by by deleted.

108 Replacing oftentimes deleted.

109 The whole passage from And to mischief with it is inserted in the margin, keyed to a mark at this point in the text.

${ }^{110}$ Followed by an illegible deleted word: dif [?].

111 Followed great deleted.
} 


\section{Boyle versus the Galenists}

his Launcet freely in Difficult Cases, will do his Patient no mischief with it. One of the best $\&^{112}$ successfullest Doctors I had then ever known, $<\&>$ who was much esteem'd for his very learned Writings, tho' $<\mathrm{I}$ found him $>\mathrm{a}^{113}$ very cautious Practitioner, kill'd himself by such a mistake. For having in an Hospital newly committed to his Care, contracted a Distemper which he judg'd to be a Simple Feaver, He (who had a very full habit of Body) bid the Chirurgeon of the Place take from him so many Ounces of Blood. And thô, because the Doctor was a Stranger there, the Chirurgeon honestly told him that he thought the Feaver rife in that Hospital was very malign; yet the Physician was so confident of his own skill that he almost constrain'd him to open a vein, but had not ${ }^{114}$ bled the quantity prescrib'd, before he found such a Change in himself, that he put a sudden stop to the Blood, \& ask'd the Chirurgeon pardon for not having taken his advise; for which Error to my great grief, he soon after paid his Life. Nor are very <great Losses of Blood ${ }^{115}$ alwayes safe, even when the mischief they do does not presently appear. And I remember I have /fol. 116v/ too truly foretold Hydroptical Distempers to more than one considerable person, that notwithstanding my Disswasions, were encourag'd by learned men not to husband their Blood. And therefore I cannot but commend \& wish good success to the Endeavours of some ingenious Physitians, that try to find out wayes of curing even Pleurisies \& Rheumatisms, if not ${ }^{116}$ without any, yet without frequent Phlebotomies, which some Experience has long ago perswaded me to be a possible thing.

Emetics I take to be one ${ }^{117}$ of the most efficacious <sort of> Medicines that is [sic] vulgarly known, \& do oftentimes, almost in a trice, perform that which neither Bleeding, nor Purging, nor both, would in a long time, if ever, be able to do. But there are so many things that contraindicate [sic] vomits, especially the more brisk sort of them, that unless a Physician be very cautious to whom $\&$ in what Cases he administers them, they may oftentimes do the Patient more harm than good. Insomuch that in Holland, where yet ${ }^{118}$ people are stronger, \& use a much fuller dyet, than in Italy, Physicians seldom dare <to prescribe > \& Patients will seldomer dare to take, a vomit: which some of their Practitioners deservedly complain of. ${ }^{119}$ Which brings into my mind, that ${ }^{120}$ one of the eminentest \& most experienc'd $<$ Members ${ }^{121}$ of the most learned Colledge of London, who was Physician to <some $>^{122}$ Relations of mine, (which gave me occasion to know him) ${ }^{123}$ of whom it has been credibly affirm'd to me, that he would scarce in a whole Twelvemonth give an Emetic. But if he were press'd <to do it>, would rather shift off a Patient to some other Physician, that fear'd less than He to use ${ }^{124}$ a Remedy in His Judgement so unsafe. 'tis certain that severall Times strong Emetics have had very ${ }^{125}$

\footnotetext{
112 Followed by an illegible deleted word: happi[est] [?].

${ }^{113}$ Altered from as. Later in the sentence, $\mathrm{He}$ is altered from $h e$.

114 Followed by were [?] deleted.

115 Replacing large Phlebotomies deleted.

116 Followed by without deleted (at end of line).

117 Altered from some.

118 Altered from something else.

119 The whole passage Which brings ... so unsafe is inserted in the margin, replacing But deleted in
}

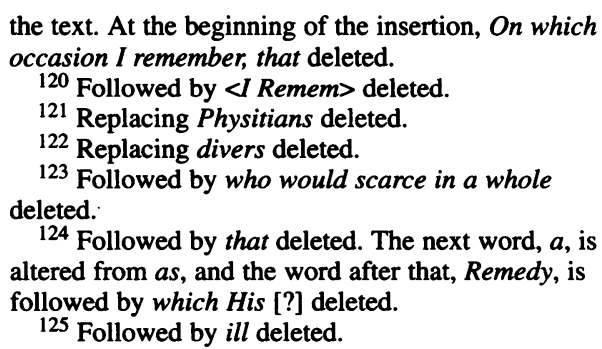




\section{Michael Hunter}

mischievous, \& sometimes fatal Effects, by breaking of veins, ${ }^{126}$ exciting Convulsions $\& c$. Thô, to add that upon the by, they $<$ may be $>^{127}$ made less offensive, or more safe, to many Patients, by <frequently> giving, whilst the Medicine works, good draughts of Posset-drink or very thin Broth./fol. 116/

Purging Medicines, thô generally speaking they are ${ }^{128}$ wont to work more safely than vomits, yet the Effect is usually more uncertain, $\&^{129}$ also less efficacious $\&$ consequently cannot but in divers ${ }^{130}$ junctures of Circumstances be unsafe. On which occasion I remember, that the famousest Commentator upon Hippocrates, the learned Prosper Martianus observes, that that ${ }^{131}$ <experienced> Oracle of Physicians scarce ever $<$ particularly> recommends the use of meer Cathartics: but, when he would evacuate by Medicines, is wont to do it by vomits. ${ }^{n}$ But, to let that pass, there are three ${ }^{132}$ frequently occurring Cases, wherein one may observe Purging Medicines to be unsafe.

The First is when the Medicine it self is naturally dispos'd to work violently, $<\&$ much to weaken the Patient> as Elaterium, ${ }^{\circ}$ white Hellebor, \& divers others; ${ }^{133}$ which therefore the more cautious <sort of $>^{134}$ Physicians are very shy of imploying, unless in robust Bodies, \& against stubborn Diseases.

Secondly, ${ }^{135}$ Purges that are not Drastic, may yet be unsafe, if they be given to Patients for whose Natures they are unfit; of which I have observ'd severall odd Examples, where very benign ${ }^{136}$ Cathartics have produc'd threatning Superpurgations in Persons that were not considerably distemper'd before. And I had a near Kinswoman, that thô otherwise vigorous \& not very Hysterical, was wont by Purging Medicines, thô given perhaps but for prevention, to be cast into Convulsive Fits that frighten'd the Bystanders.

And Thirdly, even gentle Cathartics may be dangerous, if they be ill $^{137}$ suited to the $<$ Patients> Dystemper. For <sometimes> ${ }^{138}$ an Humour /fol. $115 \mathrm{v} /$ that would be Morbific, is so contemperated or fetter'd by another, which it self also ${ }^{139}$ would be better out of the Body than in it, that by this ${ }^{140}$ proscription of one the other becomes active $\&$ predominant, $\&$ on that account able to do more harm than it could do before. Besides in

\footnotetext{
n Prosper Marziano (1577-1622); Boyle probably refers to his Magnus Hippocrates Cous explicatus
}

\footnotetext{
126 Followed by produc deleted.

${ }^{127}$ Replacing are deleted.

128 Followed by wont [?] deleted.

129 Followed by commonly deleted.

130 Followed by cases deleted.

131 Followed by a blot or deleted letter.

132 Altered from something else: the [?].

133 Followed by which making a great

Commotion in the deleted.

134 Replacing among, also inserted above line.

135 Followed by $P u$ inserted above the line but deleted and Medicines deleted.
}

(1626).

o Juice of wild cucumbers. 


\section{Boyle versus the Galenists}

some Cases, the very agitation of the Blood that is the usual effect of Purging Medicines, may do mischief, as ${ }^{141}$ may be not seldom observ'd, when ${ }^{142}$ Physicians < unwarily> give Purging Medicines in Inflammations. And I have known some of the ablest of that profession complain of the Mischief, that in their Judgment by giving even ${ }^{143}$ gentle Cathartics in Continued Feavers, <as if $>$ the Commotion made by the Medicine increas'd that <which it found $>$ made by the Disease. This brings into my mind, ${ }^{144}<$ that I have known $>$ some persons who $<$ being $>^{145}$ more than ordinarily Podagrical, ${ }^{p}$ seldom took a Purge, thô but a mild one, without having it in very few dayes attended with a Fit of the Gout. And sometimes too, if the Physic misses working, ${ }^{146}$ either it self does mischief by agitating ${ }^{147}$ Noxious Humours that it does not Evacuate, or it puts the Physician upon venturing to do his Patient a mischief to carry it off. Besides that in divers persons, especially ${ }^{148}$ sickly ones, it oftentimes awakes some ${ }^{149}$ sleeping Ferment or /fol. 115/ some Peccant Humour, that lay quiet before, \& by unseasonable or <immoderate> 150 agitation, hightens it so as to become the Cause of a Disease. To this may be added, that sometimes the very matter <even of a gentle $>^{151}$ Cathartic may be hurtfull by the other Qualities it has, besides that of Evacuating by Siege, as thô Aloes be either the Basis, or at lest a considerable Ingredient, of almost all the Purging Pills in some Dispensatoryes, it does ${ }^{152}$ heat $\&<$ much> attenuate the Blood, ${ }^{153}$ which makes it <on many occasions> unsafe to be given, $\&$ particularly to those that are ${ }^{154}$ subject to the 'Emerods, whose Pains it seldom fails <either $>$ to bring on ${ }^{155}$ or to exasperate. And to those that are subject to spit Blood, Aloes proves oftentimes a dangerous Remedy to those whose Bletz [sic] ${ }^{156}$ As I remember that ${ }^{157}$ not long since <upon> The Knowledg ${ }^{158}$ I had of the Constitution of a very ${ }^{159}$ eminent person; I foretold him that if he $/ \mathrm{fol} .114 \mathrm{v} /$ persisted in the use of Aloetic Medicines, he would incur a great danger of his Life, which Prediction ${ }^{160}$ was too well verify'd by severall Distempers, ${ }^{161}<$ to $>$ which the great Loss of Blood I fear'd < for $>$ him, which mov'd him to say $a^{162}$ while before that if he had follow'd my repeated Advice, he $<$ had ${ }^{163}$ not been reduc'd to that $<$ sad $>$ Condition.

${ }^{\mathrm{P}}$ Suffering from gout in the feet.

\footnotetext{
${ }^{141}$ Followed by a deleted character: $y$ [?] Four words later, seldom is duplicated by untrully [?] but not deleted.

142 Followed by unwary deleted. The inserted unwarily is duplicated, and the first deleted.

${ }^{143}$ Followed by quills in [?] deleted.

144 Followed by that I have known [?] deleted.

145 Replacing were deleted.

146 Altered from something else.

${ }^{147}$ Followed by $\operatorname{Pr}$ deleted.

148 Followed by valetudin deleted.

149 Followed by Peccant Humours deleted.

${ }^{150}$ Replacing excessive deleted. The next word, agitation is followed by exalt it deleted.

${ }^{151}$ Replacing of the deleted.

152 Followed by $p$ [?] deleted.

153 Followed by that cause many Persons deleted.

154 Followed by any way deleted. Three words later, the is followed by Piles deleted, and the next word, 'Emerods, is followed by singly [?] deleted.
}

\footnotetext{
155 Altered from one.

156 Sentence incomplete: the text is written hastily at this point.

${ }^{157}$ Followed by not deleted. Three words later, since is followed by I foretold a very eminent person, [that del] upon the knowledge of his Complexion, that if he persisted in the use <of> Aloetic Medicines, would incur great danger. deleted.

${ }^{158}$ Followed by of his deleted.

159 Followed by in deleted. Two words later, person is followed by two hastily written deleted words: that appeare [?].

${ }^{160}$ Followed by a Hydropical deleted.

161 Followed by that th [?] deleted. Six words later, of is followed by $H$ deleted.

162 Followed by mat [?] deleted. Five words later, he is followed by only [?] deleted.

163 Replacing would deleted. Three words later, reduc'd is duplicated by deplo but not deleted.
} 